\author{
Benjamin Tur \\ University of Lausanne \\ Jennifer Harstad \\ University of St-Gallen \\ John Antonakis \\ University of Lausanne \\ Accepted for publication at \\ The Leadership Quarterly
}

\begin{abstract}
Authors Notes
This research benefitted from funding received from Swiss National Science Foundation (Project No. 100018_169793 to Christian Zehnder and John Antonakis). Address correspondence to John Antonakis, Faculty of Business and Economics, University of Lausanne, Internet 618, Lausanne, CH-1015 Switzerland. E-mail: john.antonakis@.unil.ch
\end{abstract}

Publisher's note: This article was handled by a former editor.

Research data: The data for this article are available on Mendeley:

http://dx.doi.org/10.17632/td6j468vfp.1 


\title{
Effect of Charismatic Signaling in Social Media Settings: Evidence from TED and Twitter
}

\begin{abstract}
Informal leaders in social media currently characterizes a large part of political and economic communication on various challenges societies face, whether localized or transborder (e.g., COVID-19 pandemic, global warming). Scholars have theorized that charismatic signaling is effective in informal leadership settings; yet empirical evidence remains scarce in understanding a ubiquitous phenomenon that marks our times and plays an important role in shaping public opinion. In this article, we used two unique data sets extracted from social media to investigate the success of charisma for informal leaders, leaders who signal their beliefs and preferences to others but having no formal authority over them. Social media offers us a standardized medium as well as a natural environment to test our predictions. Using a sample of TED talks and tweets, we coded for objective markers of charisma and found that using more verbal charismatic signals predicted (a) higher views for TED talks as well as higher ratings for the extent to which the talk was found to be inspiring - beyond attractiveness and nonverbal behavior — and (b) more retweets. We discuss the implications of such results for both theory and practice in the media age.
\end{abstract}

\section{Keywords:}

Charisma, informal leadership, influence, social media, leader-follower relationship; TED; Twitter. 


\section{Effect of Charismatic Signaling in Social Media Settings: Evidence from TED and Twitter}

Can charisma help individuals gain social influence as leaders in the digital sphere? Organizational boundaries have been changing for some time now (Afuah, 2003). Individuals are increasingly exerting influence in relationships that are not clear cut in terms of hierarchy and for which leadership is not institutionalized or formal (Bass \& Bass, 2008). However, the workings of leadership in digital environments, which characterize much of current social interactions, have been largely ignored by leadership scholars (Avolio, Sosik, Kahai, \& Baker, 2014).

Social media settings that mark our times provide a unique and ubiquitous platform for formal and informal leaders to exert social influence. The massive amount of information circulated by various individuals on social media because of the COVID-19 health crises is a good example. Beyond the regular use of social media by government or business leaders to reach out to citizens, constituents, or customers, what is particularly interesting concerns the leadership of individuals with no formal authority.

Examples vying to change mindsets include Dr. Anthony Fauci, who although appointed as member of the U.S.'s Coronavirus Task force, does not have direct authority over the citizens of the U.S.A; yet, he embodies America's struggle against the virus and misinformed positions (BBC News, 2020). Didier Raoult, a French doctor who used social media to share his rather unscientific views on the COVID-19 (i.e., promoting hydroxychloroquine as a remedy to COVID-19) and strongly shaped a portion of French public opinion during the crisis (Sayare, 2020) is another case in point. Environmental activist Greta Thunberg, who has a large following and has influenced the actions of millions of people throughout the world using social media (Haynes, 2019), is another great contemporary example. 
Apart from their influence on others, and even though they have science on their side, Fauci and Thunberg also attract the ire of detractors and trigger massive chatter on social media (Specter, 2020; Stracqualursi, 2019). Reassuringly though, Fauci is currently more trusted than is Donald Trump, the President of the United States and so too are scientific experts in general (Sanger-Katz, 2020). Understanding what makes for effective leadership in media settings where there is no formal authority has important implications, particularly with respect to the diffusion of political and economic policies, scientific knowledge, or matters of public interest.

In the present study we focus on one aspect of leadership in digital settings: Charisma and its influence in social media platforms. Charisma is theorized to work from a distance and via digital means (Antonakis \& Atwater, 2002), and is a potent form of social influence per se. However, it is still not clear whether charisma can have an impact via a digital medium especially a type that is informationally frugal and which does not allow the transmission of nonverbal information (e.g., Twitter, see Avolio, et al., 2014). At this time, scholars have only provided evidence of the effects of charisma in formal leadership contexts, whether distant or not (Flynn \& Staw, 2004; Jacquart \& Antonakis, 2015). Yet, many of the social media influencers appear, at least anecdotally to be charismatic. Thus, our intention is to scientifically examine whether charisma matters in such contexts, where oftentimes public opinion battles often occur. To this end, we add to the leadership literature in three ways.

First, we examine whether charismatic signaling (i.e., the use of verbal and nonverbal behaviors to communicate emotions, symbols and values, Antonakis, Bastardoz, Jacquart, \& Shamir, 2016) has a quantifiable impact on measures of influence in digital settings and where leadership is informal. We used field data from two sources (i.e. TED talks and Twitter)—which, given their standardized format and data availability — grant us with an unusual level of control (Bamberger \& Pratt, 2010). In addition to providing a relevant example of social interaction 
where individuals jockey for status and social influence by signaling their skills and ideas, social media also provide a robust environment to test our hypotheses without the potential cofounding effects stemming from power derived from formal (i.e., hierarchical) leadership influence (i.e., viewing a TED talk or promoting it is a purely voluntary action on the part of the follower).

Second, we provide a strong test of whether objective markers (signals) of charisma, as a methodologically robust alternative to perceptual measures of charisma, matter for leader outcomes. Unlike perceptual measures of leadership or of outcomes, objective measures are particularly advantageous in order to avoid various sources of endogeneity bias (i.e., perceptions of charisma can be tainted by a host of observed and unobserved variables, see Hansbrough, Lord, \& Schyns, 2015). Thus, in addition to extending our understanding of the effects of charismatic signaling, this study contributes to the literature by providing evidence that objective markers and objectively measured outcomes should be preferred, when possible, to perceptual measures.

Third, as concerns the TED study, we will investigate whether the effects of verbal charismatic signaling go beyond nonverbal behavior, including facial attractiveness. There is a persistent belief especially in popular circles, that nonverbal communication is more important than is verbal communication. For example, Nguyen notes: the "breakdown of human communication [is] 7 percent spoken words, 38 percent tone of voice, and 55 percent body language. While some disagree on those numbers, all agree nonverbal communication dominates verbal." (Nguyen, 2014). This oft-repeated claim incorrectly stems from previous work examining the congruence of nonverbal emotion with single communicated words (Mehrabian \& Wiener, 1967). For facial appearance, abundant research shows that it matters much for leader selection and outcomes in general in low information environments (Todorov, Olivola, Dotsch, \& Mende-Siedlecki, 2015). As such, appearance could feed into ratings of leadership and outcomes. 
However, in observational studies scholars often do not control for appearance or nonverbal behavior when measuring leadership and predicting outcomes, thus potentially exposing their estimator to a serious endogeneity problems (due to omitted variables). Thus, it is currently unclear if measures of leadership are confounded by leader looks or other nonverbal signals. Moreover, it is not clear if an initial classification, which can quickly occur on the basis of facial appearance and nonverbal behavior, can be overridden by verbal charismatic signaling (Antonakis \& Eubanks, 2017).

Overall, we believe our work has important theoretical and practical implications for leadership in general and informal leadership more specifically. As concerns the latter, that activists, bloggers, and the like use the social media pit to engage followers and promote their ideas, investigating whether charismatic signaling can help to gain social influence is both timely and necessary.

\section{LITERATURE REVIEW}

\section{Defining Charisma}

Research on charisma has historically focused on how charismatic leaders affect followers. First defined as some kind of "supernatural" quality (Weber, 1947, p. 329) and then proposed as a stand-alone leadership theory (House, 1977), charisma was then enveloped in transformational leadership (Bass, 1985). A common feature of these foundational works is the definition of charisma with unobservable qualities (i.e., "supernatural qualities" or "gift") or definition of charisma both in terms of general behaviors and outcomes. For example, "idealized influence" (Bass \& Avolio, 1995) refers to followers' attribution of a leader's ability to instill trust in followers, appear powerful, or to convey a sense of mission and measured as such. However, what makes a leader instill trust or seem powerful? Trust and seeming powerful are outcomes of some process; moreover, coupled with the vagueness of the measure, and a host of 
other methodological limitations, including affect for the leader (Yammarino, Cheong, Kim, \& Tsai, 2020), suggests that such measures cannot be modeled as causes of other outcomes (Antonakis, et al., 2016; van Knippenberg \& Sitkin, 2013) nor can some of these measures be manipulated (Antonakis et al., 2016). Table 1 provides a brief overview of conceptualizations of charisma, and shows researchers should show a strong preference for the signaling perspective (we elaborate on the strengths of using a signaling approach later).

Numerous scholars have reacted to fundamental issues concerning charisma and have suggested that charisma should evolve in a construct in its own right (Antonakis, et al., 2016; Yukl, 1999) particularly given limitations in current psychometric measures of charisma (van Knippenberg \& Sitkin, 2013). In this article, we make a distinction between charismatic leadership, which is a theory of charisma per se, and its signaling aspect; the latter is the focus of this article. Taking stock of the criticisms on poor construct conceptualization (MacKenzie, 2003) we use a current definition that helps inform an objective operationalization of charisma; in doing so, we disentangle the cause (i.e., charisma) from its effects (i.e., influence), which are two major problems identified by critics (van Knippenberg \& Sitkin, 2013). Differentiating the cause from its effects is not only a definitional issue but an empirical one. Scholars have often used perceptual measures of charisma (e.g., MLQ) to predict the causal effect of charisma on outcomes - often perceptual too — such as the quality of the relationship between the leader and his or her followers. Perceptual measures cannot be used as independent variables because they are themselves endogenous constructs; thus, even modeling objective outcomes as dependent variables will not solve the endogeneity problem because omitted variables can still account for the correlation of the leader rating and the outcome (Fischer \& Dietz, 2020). Instead, researchers should focus on objective behaviors, which are not prone to being outcomes of unmodeled process or perceptions. Drawing from this observation, we use the following definition of 
charisma, in terms of being "values-based, symbolic, and emotion-laden leader signaling" (Antonakis, et al., 2016, p. 304); signaling refers to "things one does that are visible and that are in part designed to communicate" (Spence, 2002, p. 434).

[insert Table 1 here]

Charismatic signaling occurs by means of specific verbal or nonverbal behaviors that are prototypical of charismatic leaders or individuals (Awamleh \& Gardner, 1999; Den Hartog \& Verburg, 1997; Towler, 2003). For instance, communicating metaphorically, a marker of charismatic signaling, can be objectively coded and thus does not require one to measure perceptions of observers (we detail all the charismatic signals later). Importantly, charisma from a signaling point of view explains variance that is not captured by communication skills-like speech structure or tempo of the speech—or other individual-level effects (Antonakis, Fenley, \& Liechti, 2011); it also positively affect followers' perceptions of leader outcomes at micro and macro levels of performance (Antonakis, et al., 2011; Jacquart \& Antonakis, 2015). It can be directly manipulated and explains worker performance in strongly incentivized counterfactual conditions, even if the treatment is administered by video (Meslec, Curseu, Fodor, \& Kenda, 2020).

The mechanism through which the effect of charisma is thought to occur is via “inferences” (Erickson \& Krull, 1999). Individuals develop schemas by being repeatedly exposed to attributes indicative of a prototype such that later exposure to one of few indicators is enough to trigger a schema (Jacquart \& Antonakis, 2015). For example individuals who express some prototypical behaviors of charismatic leadership (i.e., the signal) will be assumed to hold some underlying leadership qualities (e.g., strong leadership skills). The charismatic signals that individuals send are credible information about their leadership abilities to the extent that the signals are hard to emulate by low ability individuals (Antonakis et al, 2016). For example, 
wearing a yellow wig is easy to replicate by low ability individuals (beyond the point that it is hard to see how this headpiece can signal leadership ability). However, crafting a well-thought metaphor requires knowing the topic, the audience, and having strong verbal skills and intelligence. Unlike wearing a wig, these rhetorical skills are hard to acquire and thus credibleand honest—-signals of an individual's qualities. These arguments, and similar ones regarding signaling (Grabo, Spisak, \& van Vugt, 2017; Reh, Van Quaquebeke, \& Giessner, 2017) parallel discussions in economic or evolutionary models of costly signaling (cf. Bliegebird \& Smith, 2005; Spence, 2002; Zahavi, 1977).

Important to note is that the source of social influence we focus on differs from the work on persuasion of Cialdini (2001) or other related sources of influence inducing compliance due to situational forces and authority (Milgram, 1963), group conformity (Asch, 1956), or because of social norms per se (see Cialdini \& Goldstein, 2004; Cialdini \& Trost, 1998). Charisma rather refers to a broader set of information-transmission signals such as symbols, values, and emotions (Antonakis et al, 2016) that engage observers and influence the framing of events, the affective states of observers, and their behaviors; it concerns voluntary following too, which is particularly germane for obtaining social influence in informal leadership settings like those in the digital arena.

\section{Formal and Informal Leadership}

A formal leader-follower relationship is a relationship in which the leader is an institutional representative either by election or by formal appointment in an organization and where the leader has asymmetric coercive or rewarding power over subordinates (Bass \& Bass, 2008; Koslowsky, Schwarzwald, \& Ashuri, 2001). Formal leadership often implies the establishment of a hierarchy, of titles, and the bestowal of power to the appointed (or selfappointed) leader over followers or institutions, which have been purposefully created. In 
comparison, informal leaders, like those we will study in the digital sphere, do not benefit from an institutionalized leadership position or have authority over their followers; instead, they achieve social influence through other mechanisms such as expertise, referent power, informational power, legitimacy of dependence, or other inferential processes (Raven, 1993; Taggar, Hackett, \& Saha, 1999). Moreover their followers form an emergent movement (as opposed to a formal institution or group).

For us, informal leadership is somewhat related to definitions of leader emergence - yet it differs from emergence in fundamental ways. Leader emergence is usually studied in formal settings oftentimes with leaderless groups where actions of individuals require coordination (Kaiser, Hogan, \& Craig, 2008). Common definitions of leader emergence include (a) "whether (or to what degree) an individual is viewed as a leader by others" (Judge, Bono, Ilies, \& Gerhardt, 2002, p. 767); (b) “processes by which leaders came to possess leadership capacity [or] follower recognition" (Dinh et al., 2014, p. 57) or (c) "being perceived as leader-like, usually in a group of strangers," (Kaiser, et al., 2008, p. 97). Of course, in consequential settings, leader emergence at a later stage can also determine leader appointment. However, given the context we are examining, we are only interested on whether informal leaders can, in the first instance, impact others via charisma in some way, where direct hierarchy is not present (cf. Koslowsky, et al., 2001), and where they derive their power from using some means of social influence (Berdahl, 1996; Hollander, 1961). Thus, we define informal leaders as those individuals who signal their beliefs and preferences to others but have no formal authority over them.

As within a formal setting, the informal leadership effect occurs when people follow by incurring some cost - by cost we mean support the ideas of the informal leader, promoting them within their personal networks, or by acting in line with the leader's beliefs and preferences. Greta Thunberg is an informal leader because she signals her beliefs and preferences with respect 
to environment and global warming; her influence is reified in spontaneous social movements. The informal leadership process occurs because individuals choose to follow her and support her mission by expressing and spreading her word through social media, peaceful demonstration, or other costly actions.

Scholars like Weber (1968) suggested that charisma may help an individual to emerge as a leader. There is also evidence showing that charismatic individuals have a higher likelihood of being appointed to positions of leadership in political and economic institutions (Jacquart \& Antonakis, 2015). Yet, little is known about the effect of charisma in informal but consequential settings, like those characterizing the digital era, wherein influential players can have a big impact on shaping public opinion (Allcott \& Gentzkow, 2017). Given that emergent leadership is a process of social influence and that charisma can yield social influence (cf. Shamir, House, \& Arthur, 1993), we expect too that charismatic signaling positively affects social influence in digital interactions, which do not entail a formal leader-follower relationship (and of course, where the leader too is not seen face to face).

\section{Operationalizing charismatic signaling}

A common way to measure charisma is to use questionnaires like the Multifactor Leadership Questionnaire (MLQ) and to ask followers to rate a target leader on several items, which are thought to tap into various leadership dimensions. Although questionnaires grant some advantages such as cost-efficiency or ease of administration, they raise several major methodological issues, the most prevalent one being endogeneity bias (Antonakis, Bendahan, Jacquart, \& Lalive, 2010; Eden, 2020; Hansbrough, et al., 2015). All MLQ-type measures, despite their popularity, fail to measure charisma as an independent variable (Antonakis et al, 2016). That is, ratings of these measures are endogenous and can depend on a host of omitted causes, including effects of implicit theories of raters, common method biases, social desirability 
and leniency biases, hindsight bias, performance-cue biases, among other biases on the part of the raters (Antonakis, et al., 2010; Golden, 1992; Lord, Binning, Rush, \& Thomas, 1978; Podsakoff, MacKenzie, Lee, \& Podsakoff, 2003; Rush, Thomas, \& Lord, 1977). For instance, if raters have knowledge that the leader has been effective they will rate the leader higher on prototypically good forms of leadership (Lord, et al., 1978); even basic things like facial appearance can matter greatly (Todorov, et al., 2015). Because measures of perceptions and measures of outcome are confounded, they share many omitted causes and cannot be used reliably to make causal claimsthey should be modeled only as endogenous variables (Antonakis et al, 2016). How, then, should scholars model charisma as an independent variable?

As shown in Table 1, an alternative solution to questionnaire measures is the use of objective measures of charisma, where the adjective "objective" refers to the fact that these measures are free from the perceptual biases that affect MLQ-type questionnaires. Objective measures of charisma refer to a set of verbal and nonverbal signals that are theorized to trigger symbolic meanings and provide moral justifications for the mission, among other mechanisms (Jacquart \& Antonakis, 2015; Mio, Riggio, Levin, \& Reese, 2005; Towler, 2003). In practice, these charismatic signals can either be measured in archival data (or directly observed), in which case researchers code the occurrence of a given set of signals; or they can be manipulated (Antonakis, et al., 2011; Towler, 2003). Although objective measures of charisma alleviate biases linked to perceptual measures, researchers must take appropriate actions to deal with measurement error and to statistically control for possible correlates of the signals that may also correlate with the outcomes; thus, appropriate control variables must be included in the model. Previous studies have looked at verbal and nonverbal signals jointly (Antonakis, et al., 2011; Awamleh \& Gardner, 1999; Frese, Beimel, \& Schoenborn, 2003; Gordon \& Berson, 2018) or independently (Den Hartog \& Verburg, 1997; Jacquart \& Antonakis, 2015). In this study, we 
focused our attention on verbal charismatic signaling tactics and measured charisma with verbal charismatic markers; we also measured nonverbal charismatic signals (in the TED) context separately. Separating these aspects of charisma allows for some degree of comparability with the Twitter context, wherein we coded only written messages. Our measurement strategy also allows for comparability to the Jacquart and Antonakis (2015) study of U.S. presidential elections, wherein they only coded for charisma using written transcripts of nominee speeches (given that the data spanned from 1916 onward and audio/video recordings were not available for a large part of the sample). Coding only verbal signals is usually sufficient to assess charisma because verbal and nonverbal behaviors are correlated (Antonakis, et al., 2011); the latter depends much on what is being said.

Note, we are not claiming that delivery is not important; it is and both verbal and nonverbal aspects should be modeled to obtain a full picture of charismatic effect. Yet, it is hard to see how nonsensical prose and very weak arguments could influence others even if delivered with gusto. Although we believe charisma requires the use of verbal and nonverbal signaling and that both should be jointly modelled, we expect that the verbal component is more important. A useful study to examine this point is the data from Antonakis et al. (2011), Study 2, where participants viewed videos of target leaders and did not see the leaders live. These researchers modeled charisma as a total score composed of verbal and nonverbal charisma signaling. We reanalyzed this data by splitting the verbal and nonverbal charisma components, while still accounting for other fixed (constant) effects due to the individual. Results showed that only verbal charisma significantly predicted all outcomes with slight improvements in variance predicted (see Appendix I). Still to impose a more robust test on our hypotheses we will control for host of nonverbal signals including cues like attractiveness as well as voice intensity and 
pitch, body language, as well as other cues like reputation, and professional status (see Grabo, et al., 2017; Reh, et al., 2017).

Verbal markers of charisma include: using stories and anecdotes, metaphors and comparisons, rhetorical questions, three-part lists, contrasts, moral conviction, expressing the sentiments of the collective, among others (Antonakis, et al., 2011). These tactics are effective not only because of inferences observers make about the individual's abilities, but also because they affect the way people process the information transmitted. Stories, for instance, increase the likelihood that the message will be remembered and improves its understandability (Bower, 1976). Metaphors and comparisons use imagery to simplify a message, trigger emotional reactions, and increase its retention (Charteris-Black, 2005; Mio, et al., 2005); these tactics can have a strong influence on information processes and ultimately can shape thought (Thibodeau, Hendricks, \& Boroditsky, 2017). Expressing the sentiments of the collective reduces the psychological distance between the person who delivers the message and the listener. Communicating one's values signals normative values and makes the person vulnerable; they are costly too in another way with respect to the extent that the individual has to walk the talk, and it also limits the range of followers that can be influenced to the extent that the values do not overlap with those of the collective (for details see Antonakis, et al., 2011; Antonakis, Fenley, \& Liechti, 2012). Thus, the charismatic effect will only occur to the extent that the signals used are quality signals and the values resonate with the observers.

As mentioned, given the sophistication of these techniques, charismatic signaling should be honest signaling (Antonakis et al., 2016) because theoretically, producing the signal is more costly for low than for high ability (Zahavi, 1977, 1981). Thus, the signal conveys honest information on the individual's ability. Consequently, those who signal charisma should have more social influence even in the absence of authority presumably because they will be taken 
more seriously, communicate a message that better resonates with observers (and galvanize them to the extent that the values appeal to them), and leave a more vivid memory.

Although the primary interest we have is in the verbal signals we control for all important nonverbal signals too in our specifications. Nonverbal charismatic signals matter also, and include use of facial expression, body gesture, as well as use of voice (see Antonakis et al., 2011). Similar to verbal charismatic signals, nonverbal signals affect how people process information. For example, smiling can act as a reward to reinforce a behavior, a dominance signal, or a way to maintain social bonds (Martin, Rychlowska, Wood, \& Niedenthal, 2017). Nonverbal signals are also costly signals in that they convey a certain emotional state, confidence, or other information that engages the speaker in a particular course of action; moreover the emotional state conveyed reinforces what is being said (Wasielewski, 1985; Willner, 1984). As with verbal signals, nonverbal signals are honest because they are difficult to fake for those who do not really feel a certain emotional state, a particular level of confidence or sense of purpose (e.g., it is easy to smile when we feel truly happy to be on stage but harder when we feel stress and overwhelmed but want to pretend otherwise).

\section{Using social media contexts as a robust test of charismatic signaling}

Despite being unusual contexts for research on leadership, social media platforms allow for rigorous analysis of charismatic signaling and give us a number of methodological advantages (cf. Bamberger \& Pratt, 2010). First, they provide objective, and perfectly observed measures of social influence in a field setting (i.e., TED views, Tweet retweets) where social influence is an outcome of informal leadership and is defined as the ability individuals have to propagate their beliefs and preferences. Views and shares are a proxy of social influence because they increase the likelihood that the message will be propagated and accepted (e.g., see Phang, Zhang, \& Sutanto, 2013). Individuals who write tweets or give TED talks do so to share their opinions, and 
gain social influence on a web-based community (Toubia \& Stephen, 2013). Views and shares capture the performance of a tweet or TED talk because they are costly to view and promote: watching a video takes time and sharing it engages ones' reputation. Next, social media also provide standardized environments to study a phenomenon. Social media have specific rules, formal codes, and formats that provide for a homogenous testing environment that limits extraneous influences and unmodeled variance. For instance, TED talks have a set time, are given on a round red rug in front of an audience, and are part of a series of talks on various topics; videos are produced in a similar format and promoted on a common platform. Similarly, tweets are published on a standard platform, have a maximum of 140 characters (at the time of data gathering), and follow strict editing rules within a standardized layout. Both contexts allow little deviation from established norms and provide us with observations that are in a tightly controlled setting; what performance differences we observed are thus because of individuals or contextual factors that we can measure and model.

Finally, social media contexts fit our research question because they provide environments in which individuals who consume the message (i.e., receivers) probably have little or no contact with the individuals who formulate and communicate the message (i.e., senders). The weakness of social ties and the absence of reward or coercive leader power over the receivers ensures that formal leadership status, a confounding factor in typical leadership studies, is absent from the social interactions in the present studies. In addition, sharing a video or a tweet legitimizing the status of the sender and contributes to the process of leader influence. Thus, as mentioned previously regarding our contribution, such a context provides a robust environment to test the effects of charismatic signaling free from the confound of authority. Importantly too, such a context provides a strong test of whether charismatic signaling works from a distance via digital communication channels. Thus, we tested the following: 
Hypothesis 1: Verbal charismatic signaling predicts objective measures of social influence in social media contexts

Another key issue is whether we are still measuring charisma in this context. Charisma is an inferential process (Jacquart \& Antonakis, 2015). Individuals are charismatic in the eyes of others. Thus, apart from objective performance metrics, we expect that measures of charismatic signaling will be positively related to adjectives that are prototypical of charismatic leaders (e.g., that they are inspiring); we test this assertion in the context of TED talks given the availability of data ratings from video viewers. This hypothesis is akin to a manipulation check because we are not examining the impact of charisma on performance; rather, we examine if perceivers feel the consequences of charisma in a way the theory would suggest. Thus, we tested the following:

Hypothesis 2: Verbal charismatic signaling in social media predicts viewer ratings of adjectives prototypical of charismatic leaders

We tested our hypotheses using two unique data sets extracted from social media platform. In the first study, we extracted videos from TED and coded for verbal and nonverbal charismatic tactics. Controlling for different variables including attractiveness (Tskhay, Zhu, \& Rule, 2017; Tskhay, Zhu, Zou, \& Rule, 2018), we measured whether verbal charismatic tactics could predict the number of views. The second study used a similar methodology but focused on written communication; we downloaded tweets from Twitter and used retweets as a dependent variable.

\section{STUDY 1: TED}

In Study 1, we used field data from TED (https://www.ted.com/). TED is a nonprofit organization that invites speakers from various backgrounds to give talks of about 18 minutes or less on various topics. Participants usually prepare some months in advance and receive guidance from the organization, leading to relatively standardized talks in terms of structure, support, and 
delivery style. Participants deliver their talks on stage, with professional lighting and microphones. The talks are recorded with high-quality video cameras, and uploaded on the TED official website, meaning they can be watched, shared and downloaded for free (the talks are also mirrored on Youtube). The number of views indicates how many people watch a given talk and is displayed below the video.

\section{Data and sample}

We analyzed the transcripts of 240 randomly selected TED talks directly from the entire population of TED talks available on official website of TED on the day of the data collection. We chose this number of talks after running a power analysis in which we assumed half of the effect ( $r=0.31$ ) reported by Antonakis et al., (2011). Assuming the full model has an R-square of .60 , including an effect of nonverbal charisma of .023 , the power analysis suggested a minimum sample size of $n=136$ (for power of $80 \%$ ); we doubled the sample size to be on the safe side (suggesting that we would have more than $90 \%$ probability to detect the effect). We selected the 240 talks randomly. The transcripts for the talks are made available by the TED organization. We collected the dependent and control variables from various web-based sources, as indicated below.

\section{Dependent measures}

We collected two types of dependent measures to test hypotheses 1 and 2 . The first measure was the number of views per talk, a performance outcome which served as a proxy for social influence. Although some TED talks benefit from more promotion than do others, it is fair to assume that a significant part of the variance in views is attributable to the frequency at which a given video is shared or viewed following promotion by independent viewers in various ways (e.g. e-mails, Facebook or other social media postings, conversations); of course TED official organizers too promote talks they believe will be well received by viewers. Still, whether a talk 
goes on to be heavily viewed will depend in large on viewers' efforts to promote the talk on social media or by other means.

We operationalized the dependent variable of hypothesis 2 (i.e. prototypical inferences regarding charismatic leaders) by using publicly available ratings. Viewers can rate each video posted on the official website of TED with key words describing the video. We gathered data on the keywords "inspiring" and "persuasive." The data reflect the percentage for each key word that indicates the proportion of viewers who thought the video was "inspiring" or "persuasive." We collected the ratings for these two variables because these adjectives overlap with outcomes often associated with charismatic leaders (Antonakis, et al., 2011; Shamir, et al., 1993). Of course, these data are limited in that raters chose to provide these ratings (i.e., there is a selection effect, which we cannot model). Still, this endogenous choice to rate a talk as inspiring or persuasive is useful for us because the effort to provide this rating is costly and theoretically, it should be a function of how emotionally engaged viewers were when they saw the talk.

\section{Independent variables and controls}

Verbal Charismatic signaling. Many markers of charismatic signaling have been identified (Den Hartog \& Verburg, 1997; Frese, et al., 2003). In this study, we focused our attention on verbal behaviors and coded the nine verbal tactics - part of the charismatic leadership tactics — identified and tested by Antonakis, Fenley and Liechti (2011) and also used in other settings (Jacquart \& Antonakis, 2015). Using these same nine signaling tactics thus allows for a strong and comparative test regarding whether they work in informal leadership settings too.

We measured for the presence of the charismatic signals to frame the message, including (a) metaphors and analogies, (b) stories and anecdotes, (c) contrasts, (d) three-part lists, and (e) rhetorical questions as well as tactics focusing on the substance of the message including (f) 
moral conviction, (g) expressing the sentiments of the collective, (h) setting high and ambitious goals, and (i) creating confidence that goals can be achieved. Three trained coders (denoted for notational purposes $\mathrm{A}, \mathrm{B}$, and C) coded each transcript at the sentence level and reported binary measures $(0,1)$ for the presence of each tactic; we summed the tactics to derive the speech level score. The coders had high agreement with a standardized alpha reliability coefficient of .96 at the speech level; the standardized reliability coefficient at the sentence level was .81. We also computed measures of agreement at the sentence level with pairwise agreement between coders $\mathrm{A}, \mathrm{B}$, and $\mathrm{C}$ of $82.25 \%, 79.94 \%$ and $82.60 \%$ and pairwise Cohen's kappas (pairwise agreement corrected for chance effects) at $.57(S E=.01, z=113.98, p<.001), .49(S E=.01, z=98.35, p<$ $.001)$, and $.52(S E=.01, z=100.49, p<.001)$, respectively (Landis \& Koch, 1977).

Attractiveness. There is evidence that facial attractiveness provides several advantages to individuals across a wide range of situations including of leadership emergence and other measures of success (Antonakis \& Eubanks, 2017; Todorov, 2017; Zebrowitz, 1997, 2017; Zebrowitz \& Montepare, 2008) including charisma (Tskhay, et al., 2017; Tskhay, et al., 2018). Thus, given the prominence of looks on this platform, it is likely that attractiveness influences the number of views and explains why potential viewers initially click on and watch one talk rather than another. We thus collected, resized, and recolored (i.e., into black and white) pictures from TED speakers from public sources. Pictures were frontal face shots, with neutral facial expressions. We asked a sample of participants to rate pictures for attractiveness using a 9 pointLikert scale ( $1=$ Not at all attractive, 9 = very attractive); such ratings correlate strongly with objective measurement of facial symmetry (Rhodes, Proffitt, Grady, \& Sumich, 1998). We recruited 244 participants from a university subject pool, and each participant rated 10 pictures. Rating agreements were statistically significant, $F(243,2196)=4.32, r$-square $=.32, p<.001$, and agreement was relatively strong $I C C 1=.25(S E=.02), I C C 2=.77$ (Bliese, 2000). 
Control variables. We include three types of control variables to minimize the possibility of omitted variable bias: Variables about the speaker, about the event, and about the speech. In order to control for individual differences, we included sex (i.e., male $=1$, female $=0$ ), previous experience at TED $(=1$, else $=0)$, and notoriety before the talk. Controlling for speaker fame is important because, for example, Bono the lead singer of $\mathrm{U} 2$, who was one of the speakers we randomly selected, will benefit from his fan base in comparison to an unknown artist; thus, we measured fame through the length of the personal Wikipedia page one month before the TED talk was delivered. We also controlled for wearing red $(=1$, else $=0)$ because previous research suggests that this color can have a positive effect on outcomes (Elliot \& Maier, 2014), and for wearing glasses, which can have a negative effect (Tskhay, et al., 2017).

Finally and as a robustness check we included two aspects of nonverbal charismatic signals: Use of gesturing coded on a 0 (not all all) to 5 (frequently if not always) scale and voice measured using Praat, a computer program (Boersma \& Weenink, 2011). For the former, two trained coders saw the videos (without sound) and independently rated the presenters on: (a) Body gestures, that is, the target's use of arms to do rhythmic movements, or body gestures highlighting what is being said - the correlation between the coders was $r=.73$ and the concordance $\rho=.69, S E=.03$, and (b) Facial expressions, where the coders rated any gestures conveyed in the face $-r=.60$ between the two coders and the concordance was $\rho=.53$, SE $=$ .04 . We created an index, nonverbal gesturing by averaging the two dimensions, and used one rater's score to "instrument" for the other (analysis method explained below); the correlation for the two measures was $r=.69$ and the concordance $\rho=.65, S E=.03$. For the ratings of voice, we extracted audio files from the official website of TED, selected, when relevant the first three minutes and the last three minutes of the speech and used the embedded functionalities of the 
program to assess automatically (a) Pitch mean and pitch standard deviation measured in $\mathrm{Hz}$ (and their interaction) and (b) Intensity and intensity standard deviation measured in $\mathrm{dB}$ (and their interaction). We included the interactions of the two variables given that observers may be more or less receptive to variabilities at certain levels. Note, we only extracted an excerpt for comparability (given varying length of talks) and that voice parameters of individuals can be assumed to be relatively constant; indeed, voice identification algorithms are extremely accurate even when using very short inputs (Ma, Zuo, Li, \& Chen, 2020).

We used TED descriptions of the talks to classify them into exclusive categories bearing mind that the categories are general enough to accommodate similar themes, but not too specific that it requires an inordinate amount of categories. Drawing from the content of the talks and the background of the speakers, we settled on 13 categories including arts, biology, business, design, education, electronics, mechanical engineering, medicine, politics, psychology, science (i.e., chemistry and physics), space exploration, others; thus, we modeled 12 dummy variables to control for the topic of the talk, which may affect target audience sizes and interest in the talk. For example, a talk on quantum physics will probably appeal to a smaller population than a talk on personal development, all else equal (cf. Pan, Yan, \& Hua, 2016). We controlled too for the use of slides and the length of the talk, both in duration and number of characters in the talk (thus the latter would, controlling for duration reflect rate of speaking). We also controlled for the profession of the speaker (e.g., artist, engineer, doctor, business practitioner) using 10 categories (thus, we modeled 9 dummy variables). Finally, we controlled for the time effects by including the age of the talk (months old), given that older talks will have had more time to collect views. Because talks may go out of fashion with time (i.e., decay), we included too the quadric effect of time. 
At the country level, we used data from the World Bank to control for economic development and population size in the country where the conference took place (i.e., the country's logged GDP and logged population size). Controlling for these macro-level variables ensures that we capture economic and technological effects, as well as potential audience size that could affect the diffusion of the talk. Finally, we also controlled for whether the event was an official TED event - that occurs at lower frequency and usually benefits from global media coverage — or a $\mathrm{TED}^{\mathrm{x}}$ event, organized by local groups, occurring more frequently and benefiting mainly from local media coverage. The $\mathrm{TED}^{\mathrm{x}}$ talks are thus seen as less prestigious than are TED talks, though selected TED ${ }^{\mathrm{x}}$ talks are still heavily promoted via the main TED website, from which we drew the talks.

\section{Estimation method}

Although the coders were quite reliable in coding the charismatic signals, they were not perfectly reliable. Averaging the three ratings and using an index of the three raters would help alleviate measurement error somewhat, but it still does not remove the problem of measurement error entirely (Antonakis, et al., 2010; Ree \& Carretta, 2006). Thus, we must correct for this source of bias, because measurement error creates a correlation between the ill-measured variable (i.e., ratings of charismatic signaling tactics, denoted as CLTS) and the error $\epsilon$ of the variable we predict (Antonakis, et al., 2010). We opted to use an instrumental variable Poisson regression model to predict the number of views (a count variable) and an instrumental variable two-stages least squares (2SLS) regression model to predict the ratings "inspiring" and "persuasive." In both cases, we "instrumented" the charismatic signaling scores of coder A (the referent variable) with the scores of coders B and C (the instrumental variables) — refer to Equations 1 and 2. The procedure we used is called the model-implied instrumental variable (MIIV) estimation in 
psychometrics (Bollen, 1996) or the multiple indicator solution in econometrics (Wooldridge, 2010).

We used the MIIV estimator instead of a latent variable model, because the MIIV estimator readily provides a closed-form solution to the problem of measurement error in the first stage of the model and given too that simultaneous equation models with latent variables and count data can be tricky to fit; we could also rely on the extensive suite of post estimation routines (endogeneity and overidentification tests, marginal effects) provided by the analysis software Stata (2017). More importantly, as proven by Bollen (2012), the MIIV estimator purges the estimates from endogeneity by using implied instrumental variables that correlate with the independent variable but not with the error terms. Of course this model assumes, as do other maximum-likelihood factor variable models that measurement errors in the proxies are orthogonal and that the referent (or scaling) indicator is a one-to-one proxy of the latent variable (i.e., its loading is constrained to unity).

We estimated the following models, using an iterated generalized method of moments (GMM) estimator, which provides efficiency gains in finite samples (Hall, 2005), combined with a sandwich estimate of the variance (i.e., robust standard errors). The first model is an instrumental-variable Poisson regression (where the predicted value of $C L T_{A}$ from Equation 1 is used in Equation 2; note, in the case of maximum likelihood estimators, the disturbances of the two equations are allowed to covary to account for the endogeneity of the regressor in the first stage model):

First stage:

$$
C L T_{A}=\pi_{0}+\pi_{1} C L T_{B}+\pi_{2} C L T_{C}+\sum_{k=1}^{43} \xi_{k} \text { Controls }_{k}+v
$$

Second stage: $\quad$ Views $=\beta_{0}+\beta_{1}$ CLT $_{A}+\sum_{k=1}^{43} \delta_{k}$ Controls $_{k}+e$ 
The second model is an instrumental variable, 2SLS regression model (where the predicted value of $C L T_{A}$ from Equation 3 is used in Equation 4):

First stage:

$$
C L T_{A}=\mu_{0}+\mu_{1} C L T_{B}+\mu_{2} C L T_{C}+\sum_{k=1}^{43} \mu_{k} \text { Controls }_{k}+\xi
$$

Second stage: $\quad y_{z}=\omega_{0 z}+\omega_{1 z} C L T_{A}+\sum_{k=1}^{43} \tau_{z}$ Controls $_{k}+w_{z}$

Where $y_{z}$ (an element of 1,2) and refers to the two dependent variables, for two separate outcomes, "inspiring" and "persuasive." Note, because the dependent variables are proportions out of 100 (i.e., that can be transformed to a 0 to 1 scale) and thus bounded, we estimated the mode using a logit transformation of the dependent variable (Baum, 2008). For the models where we included gesturing, we used the same procedure. Note, regressing the scores of the coders on the modeled independent variables indicated that one of the coders was significantly biased by the facial appearance and sex of the presenters, $\chi^{2}(4)=24.18, p<.001$; the other was biased too, but less so, $\chi^{2}(4)=7.86, p=.10$. Thus, we instrumented the most biased coder ratings with the ratings of the other coder (that we control for facial appearance and sex, though does mitigate this problem).

\section{Results}

Refer to Table 2 for the means, standard deviations and correlations of key variables. [Insert Table 2 about here]

First, we report on the distribution of the average charismatic signaling scores (average score across three coders) to examine if there was systematic bias-stemming from selection (i.e., speaker selected on charisma or trained to increase it) — in the scores. We report on the raw distribution (Doornik-Hansen test of normality, $\chi^{2}(2)=60.24, p<.0001$ ) and that of the views 
conditioned on all the controls (Doornik-Hansen test of normality, $\chi^{2}(2)=2.62, p=.27$ ); the latter is important to do given that duration and words spoken, at the minimum, necessarily set the higher bound of the charisma score (and the rest of control are important too; overall, all the controls account for $71.06 \%$ of the variance in the charisma scores). As Figure 1 confirms too, the predicted charismatic signaling scores are normally distributed, suggesting little selection.

[Figure 1 here]

Next, we report the results of the hierarchical regression analysis in Tables 3 . The results supported Hypothesis 1 and indicated that adding charismatic signaling positively predicted views, regardless of whether we added measures of voice or nonverbal gesturing to the model $(\beta$ $=.02, p<.05)$. Note, the number of views were collected in June 2016 and all tests reported use this data. As a robustness check, we also estimated the model using the data we had initially gathered on the TED talks (i.e., March 2015); we also rechecked the estimates using more recent views (i.e., January 2018). The estimates, rounded, were precisely the same (i.e., $\beta=.02, p<$ $.01)$; this result is unsurprising given that the views in the three time periods correlated .99 upwards.

In terms of instrument strength, the Wald test (Sanderson \& Windmeijer, 2016) for the excluded instruments in the first stage equation was highly significant Model $2 F(2,196)=$ 117.92, $p<.001$, Model $3 F(2,196)=120.49, p<.001$, and Model $4 F(3,195)=$ $50.89, p<.001$. Overidentifying restrictions were not rejected for the instrumental-variable Poisson model for Model $2\left(\right.$ Hansen $J$ test $\left.\chi^{2}(1)=1.89, p=.17\right)$, Model $3\left(\right.$ Hansen $J$ test $\chi^{2}(1)=$ $.57, p=.45$ ), and Model 4 (Hansen $J$ test $\chi^{2}(1)=80, p=.37$ ); thus the models were correctly specified. However, given that obtaining fully unbiased estimates of nonverbal behavior was challenging and given that the estimate of verbal charisma did not change we can interpret 
estimates from all models, though for the marginal effects we will use Model 3, which is the most objective one (ratings of charisma were on transcripts and were thus unaffected by the appearance of the target individuals). To better see the effect size, and for ease the interpretation of the Poisson regression coefficients, which are exponentiated, we computed predictive margins as a function of charismatic signaling scores. We found that using 10 more verbal charismatic signaling tactics increases the number of views by $21.41 \%$ on average (see Figure 2 ).

[Figure 2 about here]

Verbal charismatic signaling also predicted speakers being perceived as "inspiring" $(\beta=$ $.01, p<.01)$ regardless of controls entered; again overidentifying restrictions held: All overidentification test were non-significant $(p>.10)$. Verbal charismatic signaling also predicted ratings of being seen as "persuasive" $(\beta=.02, p<.01)$ irrespective of controls; however, because the overidentification test was rejected we used a different referent indicator (that acted as the scaling indicator for latent variable, which gave a non-significant overidentification test); thus, the results regarding persuasiveness should be interpreted with caution. See Tables 4a and 4b. Overall, these results provide partial support for Hypothesis 2.

As for control variables, we found a highly significant effect of attractiveness on views, which is in line with previous research on facial cues and influence (Todorov, 2017). For instance, the difference in views for a person having been rated $1 S D$ below the mean compared to a person rated $1 S D$ deviation above the mean resulted in $+72.85 \%$ (i.e., $1,189,334$ vs $2,055,804$ views). To put the verbal charisma effect into perspective $1 S D$ below the mean suggested 939,629.50 views; however, $1 S D$ above the mean suggested $+163.77 \%$ more views (i.e., 2,478,429). Thus, the relative effect of verbal charisma was quite strong. Looking at average marginal effects, we also found that gesturing played no role, and notoriety mattered for views and persuasiveness. Interesting too, we found that speakers who had the low intensity variation 
also had the highest number of views. As for the interaction, the relation between intensity and views was negative for low levels (-1SD from mean) of intensity (and flat for high levels, +1SD from mean, of intensity). As a robustness check, we examined the predictive power of an index of charismatic signaling (sum of verbal and nonverbal and instrumented by the separate verbal and non-verbal factors). Overall, results were not affected by much; the overidentification test was passed and the marginal effects were overall very similar.

As a further check, and given we had some decent variation in length of talks, we included duration and number of characters in the talk as excluded instruments (included only in the first stage regression). These variables necessarily determine the upper bound of tactics delivered. Thus, we re-estimated Models 3 and 4 using this specification, as reported in Table 3 , columns 6 and 7. All substantive results basically remained unchanged and the models were properly specified with instruments being very strong: $F(4,196)=199.33, p<.001$ and $F(5,195)=36.23, p<.001$ respectively. Also, the overidentification tests were nonsignificant indicating they did not violate the exclusion restriction: Hansen $J$ test $\chi^{2}(3)=2.90(p=.41$ and Hansen $J$ test $\chi^{2}(3)=3.62(p=.31)$ respectively. Note, given that the two instruments are highly correlated, $(r=.90)$, leaving out number of characters did not alter the results (and instrument strength increased, $F(3,196)=264.31, p<.001$ and $F(4,196)=41.24, p<.001)$; the specification worked too if we included characters as a control variable.

The results of Study 1 generally support our hypotheses that verbal charismatic signaling increases social influence in a digital settings, even in the absence of formal leadership and that this signaling predicts prototypical adjectives associated with charismatic leaders. We found these results despite including very robust controls including nonverbal behaviors, looks, as well as many event and country-level control variables. 
[Insert Tables 3, 4a and 4b about here]

\section{STUDY 2: TWITTER}

In Study 2, we used field data from Twitter (https://www.twitter.com). Twitter is a social network that allows users (i.e., tweeters) to write or share short text messages called tweets to an audience of subscribers (i.e. followers). Others can choose to follow the tweeter (and hence are denoted "follower"). The followers get to see the tweets of all the tweeters they follow; however tweets are visible to all Twitter subscribers if they search for particular terms or hashtags (i.e., trending term) or if they visit the tweeter's page.

A restrictive messaging policy applies and limits tweets to a maximum of 140 characters (at the time we gathered the data - this policy has recently been relaxed to allow for 280 characters). As such, Twitter shares similarities with TED and supplies a standardized medium to test the effects of charismatic signaling on a measure of social influence. Twitter is a free service and a communication medium that is exclusively text-based (though a tweet can include images, video links, and other graphics). Thus, it provides a more difficult environment than does TED to test verbal charismatic signaling because followers are only exposed to verbal behaviors and this in a very terse information environment.

\section{Data and sample}

To maintain a manageable dataset and to ensure that statistical assumptions would be met for clustering due to nestings (cf. Cameron \& Miller, 2015, who recommend at least $\mathrm{n}=50$ clusters), we collected tweets from 60 individuals during a three-month timeframe. Because Twitter is often used for other purposes than sharing beliefs and preferences (e.g., individuals might use Twitter to share a location or a holiday picture), we narrowed our sample to two specific sub-groups of users (CEOs and politicians), which we assumed, used Twitter as a platform to gain social influence. The sample includes 30 CEOs and 30 members of the US 
Congress (evenly distributed between Democrats and Republicans), chosen at random from publicly available lists and after excluding inactive Twitter accounts. Given the tradeoff between within and between sampling units, we randomly selected about 50 tweets from each tweeter resulting in a sample of 2,964 tweets nested under 60 tweeters; these sample sizes are large enough to ensure sufficient power for phenomena having medium effects (Scherbaum \& Ferreter, 2009). Note that we selected our tweets from a specific timeframe; as such we keep constant any events and situations that could have had an influence on followers' attributional processes (cf. Jacquart and Antonakis, 2015). By drawing tweets from the same time-frame, we ruled out the effect a specific event may have had on the number of retweets (e.g., tweets on 9/11 may trigger more retweets than tweets on a regular Tuesday morning). Because of the network policy that applied on Twitter at the time of the data collection (i.e., in December 2011), the maximum number of shares (i.e. retweets) displayed was limited to 100 with tweets receiving more than a 100 tweets being displayed as " $100+$ ". By constraining the variation of the dependent variable, the estimate is more conservative than if the number of retweets had a greater variation. Tweets with strictly more than 100 retweets were coded as 100 (though we do make a provision for the censuring effect by also estimating the model using Tobit regression).

Note, even though nowadays Twitter reports the precise number of retweets of tweets, it makes no sense for us to attempt to use the data on the actual retweets today because we would model conditions that were not experienced by users at that time. A tweet with say 550 retweets or a tweet with 102 retweets was seen as the same by all users (i.e., 100+). The probability of a "bandwagon" effect— that individuals may tend to retweet a highly popular tweet—was not present for those seeing the tweet and the precise number of retweets. Thus, because all tweets over 100 retweets were treated in the same way at that time, it is logical too for us to analyze the data in its natural state for the time and not to attempt to model the actual (current) retweets. 


\section{Dependent measure}

We collected the number of shares (i.e., retweets) as a proxy for social influence. Retweets or shares are costly not only in terms of time and energy but also because of the reputational cost associated to the action of sharing someone else's tweet. Like in Study 1, it is fair to assume that users of Twitter share a tweet if they have been inspired or convinced by its content.

\section{Independent variables and controls}

Charismatic signaling. We operationalized charismatic signaling using the same nine verbal behaviors as in Study 1. Again, three trained raters (Coder A, B, and C) coded the entire dataset and reached a standardized alpha reliability coefficient of .74. Two out of three raters were the same as in Study 1. Pairwise measures of agreement between coders A, B and C are $77.50 \%, 80.09 \%$ and 79.89 and pairwise Cohen's kappa (pairwise agreement corrected for chance effects $)$ are $.38(S E=.02, z=23.11, p<.001), .43(S E=.02, z=27.40, p<.001)$ and .34 $(S E=.02, z=20.24, p<.001)$. Raters coded each tweet for the presence of each of the nine verbal charismatic tactics using binary measures $(0,1)$; we summed the number of instances to derive the charismatic signaling score at the tweet level. We also averaged the number of charismatic signaling tactics by author to capture the individual fixed effect of being charismatic; the cluster means capture the constant or average effect of a tweeter, thus modeling the mean difference in $y$ due to the tweeter. Including the cluster means thus ensure that the estimator is consistent (Antonakis, Bastardoz, \& Rönkkö, 2019; McNeish \& Kelley, 2018). In our specification we therefore included two variables: A first one that measures how many charismatic signaling tactics a focal individual uses on average (the contextual effect) and a second one that measures how many charismatic signaling tactics are used in a specific tweet (the within effect, Antonakis et al., 2019). Note, given that the raters were not the same as in Study 1, 
as a robustness check we validated the coding by using a deep-learning algorithm to automatically code the tweets; this algorithm was trained on the coded data from Study 1 (Garner, Bornet, Loupi, Antonakis, \& Rohner, 2019). The raw coded Twitter data (on all the tweet content) using the algorithm and at the Tweeter level correlated strongly, $r=.59, p<.0001$ with the average of the coders (who on average correlated $r=.64$ with each other).

Control variables. We include two types of control variables: Variables about the author, and variables about the tweet. We controlled for individual differences between authors by including sex $($ male $=1$, female $=0)$, whether the sender was a politician or CEO $($ politician $=1$, else $=0)$, a republican $(=1$, else $=0)$, and the number of people following the author on the day. We also controlled for tweet level characteristics and included the number of mentions (i.e. @id) and hashtags (i.e. \#id), in case they increased the prospective readership. Other control variables include the use of links to other websites within the tweet, citing a press article, using videos or pictures within the tweet, the number of days since the tweet was published (and its quadratic effect to capture decay over time), and whether the tweet refers to another author's tweet (whether modified or retweeted). Finally, we adopted Golbeck, Grimes, and Rogers's (2010) method to code for the intention of the tweet of congressman and congresswomen (e.g., request for action, direct communication, providing information, etc.), with a slight adaptation of their categorization to accommodate the particularities of corporate communication in CEO tweets.

\section{Estimation method}

As in Study 1 we used an instrumental-variable Poisson regression model (iterated GMM) for the main model; we instrumented the charismatic signaling scores of coder A with the scores of coders B and $\mathrm{C}$ to account for measurement error. Because we had panel data within the tweeter $(j)$ level (i.e. in terms of tweets and time-varying predictors), as mentioned, alongside all the time-varying control (ij) variables, we included their cluster means, as we did with the mean 
tweet level (see Mundlak, 1978, for proof of the consistency of this estimator). Doing so added 18 more control variables to the model (in addition to the time-varying 18 controls and the three $j$-level predictors, female, politician, and republican) — thus, we include $k=39$ control variables in the regression model. We also estimated the variance using cluster-robust standard errors and used other estimators as robustness checks. We estimated the following model:

First stage: $\quad C L T_{A i j}=\delta_{j}+\delta_{1} C L T_{B i j}+\delta_{2} C L T_{C i j}+\sum_{k=1}^{39} \delta_{k}$ Controls $_{k j}+u$

Second stage: $\quad$ Retweets $_{i}=\beta_{0}+\beta_{1} C L T_{A i j}+\beta_{2} C L T_{A j}+\sum_{k=1}^{39} \beta_{k}$ Controls $_{k j}+e$

The data we have made it difficult to estimate the model while accounting for all the nuances simultaneously, that is, having panel count data, an endogenous regressor, as well as censuring (lower and upper bound). Thus, we will perform robustness checks using other estimators.

\section{Results}

Means, standard deviations and correlations are reported in Table 5.

\section{[Insert Table 5 about here]}

We display the results of our hierarchical regression analysis in Table 6. For the instrumentalvariable Poisson estimator, again, the instruments were strong in the first stage: $\chi^{2}(4)=633.74$, $p<.001$. Overidentifying restrictions were not rejected, with Hansen $J$ test $\chi^{2}(2)=.34, p=.84$. The charisma score at the tweet level, the within effect, did not predict retweets; however, the charisma cluster mean $\operatorname{did}(\beta=3.85, p<.001)$. Thus, how charismatic an author is on average, the between effect (i.e., the within plus contextual effect, as estimated by the linear combination of estimators, $\beta=3.83, p<.001$ ), positively predicts retweets. This result, insofar as only the 
average effect is concerned, supports Hypothesis 1. Holding constant the individual tweets, an author that increases the average proportion of charismatic signaling tactics in tweets from $16.64 \%$ to $29.66 \%$ ( $+1 \mathrm{SD}$ ) increases the number of retweets from 3.31 to 5.46 , that is, by $64.96 \%$ (see Figure 3). It is important to point out that confidence intervals increase substantially for authors who have an average proportion of charismatic signaling tactics of $36 \%$ or more tactics because most tweets use no or one charismatic tactic. At the individual tweet level, and using from Coder A, $73.95 \%$ used zero tactics, $22.77 \%$ tweets used one tactic, $2.97 \%$ tweets used two tactics, $.27 \%$ tweets used three tactics, and $.03 \%$ tweets used four tactics. Of course, it is difficult to show more than one tactic given the maximum number of characters imposed by Twitter at that time. As a comparable measure of effect to the results in the Study 1, going from 1 to +1 SD from the mean of the average proportion of charismatic leadership tactics used by an author increased retweets $+172.11 \%$. Thus, this effect is substantively similar to the one found in Study 1. However, given the censuring, we also examined how the results held up when using other estimators.

[Insert Table 6 and Figure 3 about here]

We present results first using a two-stage least squares model (2SLS); given the censuring both at the lower (0) and upper (100) limit, it is interesting to compare the 2SLS estimate to the instrumental-variable Tobit (IV-Tobit) estimate. The difference between the two estimates is rather substantial. 2SLS suggests that a change in one unit of the average proportion of charismatic leadership tactics used by an author produces 31.82 retweets; however, the IV-Tobit estimate is 40.41 retweets (i.e., $46.89 \%$ higher).

\section{DISCUSSION}

We investigated the effect of charismatic signaling on social influence in the absence of a formal leadership role and this in a digital setting, where the leaders are not seen face to face 
(TED) or not usually seen at all (Twitter). The implications of our findings are important for leadership researchers for several reasons. First, we found that charismatic signaling increases measures of social influence, as identified with TED views and ratings as well as Twitter retweets, in the context of social media. For the latter, the level of charisma in an individual tweet did not matter. Perhaps we did not have sufficient power at the within level to detect this effect or perhaps one tweet per se is insufficient to move individuals given the terse information environment. However, how charismatic a Tweeter is on average has a very strong effect, underscoring the importance of between-leader differences in charismatic signaling. The effects were robust and practically important. In the case of Twitter, our results underscore the impact that charismatic signaling can have even in a very frugal electronic communication medium.

As for the case of TED the interesting finding is that verbal charisma has a very strong effect on views and this even beyond nonverbal charisma and attractiveness. Our results, particularly with respect to attractiveness are aligned with evidence reported by some recent work on charisma (Tskhay, et al., 2017; Tskhay, et al., 2018). However, it is important to bear in mind that Antonakis et al. (2011) did control for leader fixed-effects (which included looks, clothes, topic or other constant effects at the leader level; see their Study 2). Thus, these results are encouraging given we directly partialled out the effects of attractiveness - although observers appear to be biased by the attractiveness of a speaker, given the importance of charisma in predicting views, observers must have updated their initial classification on the basis of how much charisma the speaker signaled (i.e., observers individuated the target as a function of verbal charismatic signaling). Moreover, that verbal charisma did predict outcomes in the TED context, and nonverbal charisma did not, also adds to the literature by shining a different light on the suggestion that most important element of interpersonal communication is nonverbal. Moreover, previous literature has shown nonverbal behavior to be a reasonably good proxy of certain traits 
or to be predictive of particular outcomes; however, as concerns the latter, such research did not control for verbal charismatic signaling, whose measurement and manipulation has only been recently introduced to the literature. The verbal aspect seems to have a particular strong effect on leadership outcomes. We hope that future research examines this issue further.

Second, our findings add to the literature on effects of charismatic signaling in informal leadership contexts via digital means. Both the TED and Twitter platforms did not involve an institutionalized form of leadership and the consequence of leader charisma was experienced virtually by the followers. Also, the individuals sending tweets or delivering TED talks could not use coercive or reward mechanisms, nor did they bear a formal title or status as a leader to enforce shares and views of their message (Koslowsky, et al., 2001). We can assume that the act of following in this context is mostly voluntary for most cases. Although theorized by leadership scholars, our findings are to our knowledge, the first to provide empirical evidence that using charismatic signaling can increase social influence and contribute to the leader emergence and this from a distance via electronic communication channels.

Although our results provide evidence that social media influencers can use charismatic signaling to promote their cause, it is not clear yet whether formal and informal leadership are moderators of the effect of charismatic signaling on social influence. Perhaps past research on the moderating effects of leader distance and charisma can provide some insights (Howell \& Shamir, 2005). The context that we studied does set the leader far from observers, suggesting that the latter have less tangible or intimate information on the leader. In other words, observers have less behavioral information about the leader and they cannot observe the leader's actions in unstaged settings. Thus, it is possible that leaders' signals from distant, digital settings play a larger role in classifying leaders and inferring their qualities than they would in closer situations, where observers can use more individuating information. 
Fourth, we contributed to the literature by providing a strong test of the markers of charisma in a controlled setting; beyond freeing the data from the confound of formal leadership, the standardized settings in which we examined charisma's effects should provide further evidence of its importance in other, more general settings where influence is involved. As such, we hope that this evidence will add to the existing body of knowledge (Antonakis, et al., 2011; Jacquart \& Antonakis, 2015; Meslec, et al., 2020; Towler, 2003) and contribute to further development of objective measures of charisma. As we argued before, archival data of this sort should be preferred, when possible, to perceptual measures to avoid various endogeneity biases.

Our work also makes a contribution by extending the use of objectively-measured charismatic signaling to written communication. That we can measure charisma's impact directly in text-based communication, and this independent from nonverbal signals, suggests new research avenues should be explored. For instance, there are troves of public speeches available on top-level leaders like CEOs, country presidents, or politicians and thus many questions to answer about the impact of charisma on institutional policies or country-level outcomes (e.g., whether citizens follow government suggestions for physical distancing in the Covid-19 outbreak).

In this article, we have used different coders in Study 1 and Study 2. Although it may alter the comparability between the two studies because of individual differences in coding, the strength of the results in both studies illustrate how individuals can be trained to code verbal charismatic with a high degree of consistency. Of course, in an era of accessible big data taking this research to the next level will require the automatic coding of charismatic signals by computer; deep neural networks (using machine learning) could be very useful in this regard (LeCun, Bengio, \& Hinton, 2015). A recent software demonstration shows that the tactics can be reliably coded by computer (Garner, et al., 2019), as also seen in the robustness check of Study 2. 
Finally, if replicated, our results have also implications for training: Because charismatic signaling affects social influence for individuals without formal leadership positions in digital settings, we suggest that trainings on charismatic signaling should be directed not only to leaders but to a broader base of individuals and even to those who exercise influence but are not thought of as leaders (e.g., teachers, doctors, public policy experts), whether operating on-line or not. Interestingly, although TED speaker receive coaching and training, we assume on the secrets of great talks (Anderson, 2016; Gallo, 2014), it seems that the organization does not provide much training in charisma, as we have operationalized it.

Beyond the importance for contexts for social media contexts, of course, there are implications too for informal influence in economic or social settings including for those who have to (a) influence individuals at the interface of their organizations like shareholders or partners, (b) promote an idea or a message such as entrepreneurs pitching their start-up to venture capitalists, (c) convince a broader population to partake in public good efforts, as in the case of recycling or sustainability efforts, (d) conduct fundraising for important causes, and (e) communicate scientific findings to a broad audience.

As concerns the last point it is important to note that about $28 \%$ of the TED talks we analyzed were given by professors, and another $8 \%$ were given by medical practitioners or engineers. Individuals, who wish to increase their impact inside and outside institutions, as well as between institutions, should consider using charismatic signaling as an additional means to gain social influence and emerge as opinion leaders when using social media. The importance of scientists engaging a larger audience and influencing public debate is currently seen as a very important endeavor (Côté \& Darling, 2018), especially the ability to use effective story-telling (Dahlstrom, 2014; Krzywinski \& Cairo, 2013)-a key marker of charismatic communication. 


\section{Limitations}

Although the two studies provide some evidence for our hypotheses, there are several limitations that should be considered. Both studies use field data; despite thorough consideration about endogeneity issues, our results might be affected by omitted variables. For instance, it is not clear to us how talks are promoted by TED; if talks that are more charismatic are more heavily promoted then our estimates for charisma are overstated. Still, that the effect of charisma may possibly be built into promotion algorithms of TED highlights its importance. However, recall too also that the verbal charisma scores in the TED database were rather normally distributed; thus, speakers were neither selected on these scores nor probably trained to increase them. If speakers were selected or trained, the distribution would be negatively skewed with a high mean and low standard deviation (yet we observed the opposite in the data when not conditioning on the controls, and a normal distribution when we do). That we find essentially the same results when using talk length as instrumental variables gives us some confidence in the findings.

Still, other individual differences (e.g., intelligence) might affect views too; however, if charisma is an honest signal then at least from a predictive framework results are policy relevant. That is, having knowledge of someone's charisma provides decent probabilistic information of their influence in on-line settings (cf. Kleinberg, Ludwig, Mullainathan, \& Obermeyer, 2015). Nonetheless to obtain an unbiased and causally interpretable effect size, future research should test similar hypotheses in settings where randomization of charisma can be undertaken in more controlled platform, both for TED-type and Twitter-type contexts. Recent results in incentivized field and laboratory settings though do show a important causal effect of charisma on worker performance or in helping solve coordination problems in groups (Antonakis, d'Adda, Weber, \& Zehnder, 2020; Meslec, et al., 2020); such designs, as well as those harnessing exogenous shocks 
in the context of a natural experiment (Sieweke \& Santoni, 2020) or manipulating charisma and determining how its effect is channeled (Sajons, 2020) would be particularly useful.

Another limitation concerns our choice of the dependent variables; views and retweets might not be the best proxies for social influence. The use of "inspiring" or "persuasive" ratings as an alternative dependent variable provide some preliminary answers to this question; however, future investigation might include more straightforward measures of social influence, especially in the realm of observed behavior or institutional-level outcomes.

In addition, although we have argued that we have observed leadership in informal settings it is unclear to what extent individuals having a hierarchical relationship with the leader affected the dependent measure (e.g., hierarchical subordinates, colleagues, or friends of leaders on Twitter who retweet what is tweeted by the leader). This issue can also extend to authors or speakers who benefit from a fan base. We did attempt to partial out this factor in the case of TED (by including a measure of notoriety, the length of the Wikipedia page). In the case of Twitter we did control for number of followers, whose fixed-effect was very significant. Still, this limitation "goes against us" in that it will attenuate our findings (i.e., if individuals close to the leader reliably retweet his or her tweets, or promote their TED videos, then there will be a ceiling effect present for the case of that leader and the charismatic tactics will less likely be predictive of influence for that leader). Moreover, although the data we coded may not have been conceived by the person delivering it - meaning we measure the charisma of the speech writer - this limitation does not hamper what claims we can make, given the unit of analysis is the speech per se and its impact. Thus, to the eyes of the person exposed to the charisma, the person delivering it gets the credit.

Finally, we do not know, yet, the precise mechanism through which charismatic signaling engenders the charismatic effect. Although some "toy models" do provide some insights 
(Antonakis, et al., 2020), more basic research and theory development is required before we can build a more complete picture.

\section{Conclusion}

Our results provide initial evidence that verbal charismatic signaling determines influence success in informal leadership settings such as in social media. Indeed, our results bring to light the importance of viewing leadership as a social influence process rather than a position, where following and according status to the leader is voluntary; the context of social media, where there is no formal authority, but where charismatic signaling still had an effect allows us to make this claim. Still, the effect of charisma works in similar ways regardless of whether it occurs in formal and informal leadership settings.

Whereas TV, newspapers, books, or scientific articles formed the battlefield of ideas and aspiring leaders in the past, today things work rather differently. Increasingly, social media is becoming a dominant playfield, even triggering unforeseen collective action (Margetts, John, Hale, \& Yasseri, 2015). Individuals who once granted power by casting a vote or attributing status are now turning to social media to grant power to leaders in the form of likes and shares. Eschewing the importance of social media will not make them go away. Recent White House residents have all complemented traditional means of communication by also directly engaging with followers on Twitter, with Donald Trump taking it to a whole new level. Other country presidents and politicians (e.g., Emmanuel Macron, Justin Trudeau, Ursula von der Leyen) also use Twitter regularly. Although seen as the province of politicians, celebrities, and CEOs, social media is an important channel that activists, writers, and even scientists too (who were well represented in the TED sphere), should consider using more.

"Knowledge is power" the saying goes, and because social media gives an unprecedented tool to diffuse ideas, political positions, and values, understating how individuals can secure 
informal leadership in the digital knowledge market place is both relevant and important for theory and practice alike. As mentioned by Galetti and Costa-Pereira "In a world of "alternative facts," a powerful voice-[a TED talk] or tweet [or media briefing]—can help to improve the communication gap between scientists and the public" (2017, p. 881). Misinformation in social media is highly problematic and the failsafe way to fight it is "to harness the same sophisticated tools in the name of science that are being used to tear science down" (Thorp, 2020, p. 1405). Ironically, the importance of charismatic communication by leaders in the digital sphere, especially about public health policy, is now even more visible in the Corona fog. 


\section{REFERENCES}

Afuah, A. (2003). Redefining firm boundaries in the face of the Internet: Are firms really shrinking? Academy of Management Review, 28(1), 34-53.

Allcott, H., \& Gentzkow, M. (2017). Social media and fake news in the 2016 election. Journal of Economic Perspectives, 31(2), 211-236.

Anderson, C. (2016). TED talks: The official TED guide to public speaking: Houghton Mifflin Harcourt.

Antonakis, J., \& Atwater, L. E. (2002). Leader distance: A review and a proposed theory. The Leadership Quarterly, 13, 673-704.

Antonakis, J., Bastardoz, N., Jacquart, P., \& Shamir, B. (2016). Charisma: An Ill-Defined and IllMeasured Gift. Annual Review of Organizational Psychology and Organizational Behavior, 3(1), 293-319.

Antonakis, J., Bastardoz, N., \& Rönkkö, M. (2019). On ignoring the random effects assumption in multilevel models: Review, critique, and recommendations Organizational Research Methods, , https://doi.org/10.1177/1094428119877457.

Antonakis, J., Bendahan, S., Jacquart, P., \& Lalive, R. (2010). On making causal claims: A review and recommendations. The Leadership Quarterly, 21, 1086-1120.

Antonakis, J., d'Adda, G., Weber, R. A., \& Zehnder, C. (2020). Just words? Just speeches? On the economic value of charismatic leadership. Working paper, Available www.hec.unil.ch/jantonakis/charisma.htm.

Antonakis, J., \& Eubanks, D. L. (2017). Looking leadership in the face. Current Directions in Psychological Science, 26(3), 270-275.

Antonakis, J., Fenley, M., \& Liechti, S. (2011). Can Charisma Be Taught? Tests of Two Interventions. The Academy of Management Learning and Education, 10(3), 374-396.

Antonakis, J., Fenley, M., \& Liechti, S. (2012). Learning charisma: Transform yourself into someone people want to follow. Harvard Business Review, June, 127-130.

Asch, S. E. (1956). Studies of independence and conformity: A minority of one against a unanimus majority. Psychological Monographs: General and Applied, 70(9), 1-70.

Avolio, B. J., Sosik, J. J., Kahai, S. S., \& Baker, B. (2014). E-leadership: Re-examining transformations in leadership source and transmission. The Leadership Quarterly, 25(1), 105-131.

Awamleh, R., \& Gardner, W. L. (1999). Perceptions of leader charisma and effectiveness: The effects of vision content, delivery, and organizational performance. The Leadership Quarterly, 10(3), 345-373.

Bamberger, P. A., \& Pratt, M. G. (2010). Moving forward by looking back: Reclaiming unconventional research contexts and samples in organizational scholarship. Academy of Management Journal, 53(4), 665-671.

Bass, B. M. (1985). Leadership and performance beyond expectations. New York: The Free Press.

Bass, B. M., \& Avolio, B. J. (1995). MLQ Multifactor leadership questionnaire for research: Permission set. Redwood City, CA: Mindgarden.

Bass, B. M., \& Bass, R. (2008). The Bass handbook of leadership: Theory, research, and managerial applications (4th ed.). New York: Free Press.

Baum, C. F. (2008). Modeling proportions. Stata Journal, 8(2), 299-303. 
BBC News. (2020). The face of America's fight against Covid-19". . https://www.bbc.com/news/world-us-canada-52027201( Retrievied 28 June 2020).

Berdahl, J. L. (1996). Gender and leadership in work groups: Six alternative models. The Leadership Quarterly, 7(1), 21-40.

Bliegebird, R., \& Smith, E. (2005). Signaling Theory, Strategic Interaction, and Symbolic Capital. Current Anthropology, 46(2), 221-248.

Bliese, P. D. (2000). Within-group agreement, non-independence, and reliability: Implications for aggregation and analysis. In S. W. J. Kozlowski \& K. J. Klein (Eds.), Multilevel theory, research, and methods in organizations (pp. 349-381). San Francisco, CA: Jossey-Bass.

Boersma, P., \& Weenink, D. (2011). PRAAT: Doing phonetics by Computer (ver. 5.2. 24). Amsterdam: Institut for Phonetic Sciences.

Bollen, K. A. (1996). An alternative two stage least squares (2SLS) estimator for latent variable equations. Psychometrika, 61, 109-121.

Bollen, K. A. (2012). Instrumental Variables in Sociology and the Social Sciences. Annual Review of Sociology, 38(1), 37-72.

Bower, G. H. (1976). Experiments on story understanding and recall. The Quarterly Journal of Experimental Psychology, 28(4), 511-534.

Cameron, A. C., \& Miller, D. L. (2015). A practitioner's guide to cluster-robust inference. Journal of Human Resources, 50(2), 317-372.

Charteris-Black, J. (2005). Politicians and rhetoric: The persuasive power of metaphor. Basingstoke, UK: Palgrave-MacMillan.

Cialdini, R. B. (2001). Influence: Science and practice. Boston: Pearson.

Cialdini, R. B., \& Goldstein, N. J. (2004). Social influence: Compliance and conformity. Annual Review of Psychology, 55, 591-621.

Cialdini, R. B., \& Trost, M. R. (1998). Social influence: Social norms, conformity, and compliance. In D. T. Gilbert, S. T. Fiske \& G. Lindzey (Eds.), The handbook of social psychology (4th, Vol. 2, ed., pp. 151-192). Boston: McGraw-Hill.

Côté, I. M., \& Darling, E. S. (2018). Scientists on Twitter: Preaching to the choir or singing from the rooftops? FACETS, 3(1), 682-694.

Dahlstrom, M. F. (2014). Using narratives and storytelling to communicate science with nonexpert audiences. Proceedings of the National Academy of Sciences, 111(Supplement 4), 13614-13620.

De Hoogh, A., Den Hartog, D., \& Koopman, P. (2004). De ontwikkeling van de CLIO: een vragenlijst voor charismatisch leiderschap in organisaties. Gedrag en Organisatie, 17(5), 354-381.

Den Hartog, D. N., \& Verburg, R. M. (1997). Charisma and rhetoric: Communicative techniques of international business leaders. The Leadership Quarterly, 8(4), 355-391.

Dinh, J. E., Lord, R. G., Gardner, W. L., Meuser, J. D., Liden, R. C., \& Hu, J. (2014). Leadership theory and research in the new millennium: Current theoretical trends and changing perspectives. The Leadership Quarterly, 25(1), 36-62.

Eden, D. (2020). The Science of Leadership: A journey from survey research to field experiments. The Leadership Quarterly.

Elliot, A. J., \& Maier, M. A. (2014). Color Psychology: Effects of Perceiving Color on Psychological Functioning in Humans. Annual Review of Psychology, 65(1), 95-120.

Erickson, D. J., \& Krull, D. S. (1999). Distinguishing Judgments About What From Judgments About Why: Effects of Behavior Extremity on Correspondent Inferences and Causal Attributions. Basic and Applied Social Psychology, 21(1), 1-11. 
Etzioni, A. (1961). A comparative analysis of complex organizations. New York: The Free Press.

Fischer, T., \& Dietz, J. (2020). Measures of Authentic, Ethical, and Servant Leadership Spuriously Predict Objective Outcomes. Academy of Management Proceedings, 2020(1), 18746.

Flynn, F. J., \& Staw, B. M. (2004). Lend me your wallets: The effect of charismatic leadership on external support for an organization. Strategic Management Journal, 25, 309-330.

Frese, M., Beimel, S., \& Schoenborn, S. (2003). Action training for charismatic leadership: Two evaluations of studies of a commercial training module on inspirational communication of a vision. Personnel Psychology, 56, 671-697.

Galetti, M., \& Costa-Pereira, R. (2017). Scientists need social media influencers. Science, 357(6354), 880-881.

Gallo, C. (2014). Talk like TED: the 9 public-speaking secrets of the world's top minds: St. Martin's Press.

Garner, P., Bornet, O., Loupi, D., Antonakis, J., \& Rohner, D. (2019). Deep learning of charisma. Software Demonstration: Swiss Text Analytics Conference.

Golbeck, J., Grimes, J. M., \& Rogers, A. (2010). Twitter use by the US Congress. Journal of the Association for Information Science and Technology, 61(8), 1612-1621.

Golden, B. R. (1992). Research notes. The past is the past - or is it? The use of retrospective accounts as indicators of past strategy. Academy of Management Journal, 35(4), 848-860.

Gordon, I., \& Berson, Y. (2018). Oxytocin modulates charismatic influence in groups. Journal of Experimental Psychology: General, 147(1), 132-138.

Grabo, A., Spisak, B. R., \& van Vugt, M. (2017). Charisma as signal: An evolutionary perspective on charismatic leadership. The Leadership Quarterly, 28(4), 473-485.

Hall, A. R. (2005). Generalized Method of Moments. Oxford: Oxford University.

Hansbrough, T. K., Lord, R. G., \& Schyns, B. (2015). Reconsidering the accuracy of follower leadership ratings. The Leadership Quarterly, 26(2), 220-237.

Haynes, S. (2019, 24 May 2019). Students From 1,600 Cities Just Walked Out of School to Protest Climate Change. It Could Be Greta Thunberg's Biggest Strike Yet. Time.

Hollander, E. P. (1961). Some effects of perceived status on responses to innovative behavior. The Journal of Abnormal and Social Psychology, 63(2), 247.

House, R. J. (1977). A 1976 Theory of Charismatic Leadership. In J. G. Hunt \& L. L. Larson (Eds.), The Cutting Edge (pp. 189-207). Carbondale: Southern Illinois: University Press.

Howell, J. M., \& Frost, P. J. (1989). A laboratory study of charismatic leadership. Organizational Behavior and Human Decision Processes, 43(2), 243-269.

Howell, J. M., \& Shamir, B. (2005). The role of followers in the charismatic leadership process: Relationships and their consequences. Academy of Management Review, 30(1), 96-112.

Jacquart, P., \& Antonakis, J. (2015). When does charisma matter for top-level leaders? Effect of attributional ambiguity. Academy of Management Journal, 58, 1051-1074.

Jensen, U., Rohner, D., Loupi, D., Garner, P. N., Carron, D., Bornet, O., et al. (2020). Combatting Covid with Charisma: Evidence on Governor Speeches and Physical Distancing in the United States. Manuscript in preparation.

Judge, T. A., Bono, J. E., Ilies, R., \& Gerhardt, M. W. (2002). Personality and leadership: A qualitative and quantitative review. Journal of Applied Psychology, 87, 765-780.

Kaiser, R. B., Hogan, R., \& Craig, S. B. (2008). Leadership and the fate of organizations. American Psychologist, 63(2), 96-110.

Kleinberg, J., Ludwig, J., Mullainathan, S., \& Obermeyer, Z. (2015). Prediction policy problems. The American Economic Review, 105(5), 491-495. 
Koslowsky, M., Schwarzwald, J., \& Ashuri, S. (2001). On the relationship between subordinates' compliance to power sources and organisational attitudes. Applied Psychology, 50(3), 455-476.

Krzywinski, M., \& Cairo, A. (2013). Points of view: storytelling. Nature Methods, 10(8), 687.

Landis, J. R., \& Koch, G. G. (1977). The measurement of observer agreement for categorical data. Biometrics, 33(1), 159-174.

LeCun, Y., Bengio, Y., \& Hinton, G. (2015). Deep learning. Nature, 521, 436-444.

Lord, R. G., Binning, J. F., Rush, M. C., \& Thomas, J. C. (1978). The effect of performance cues and leader behavior on questionnaire ratings of leadership behavior. Organizational Behavior and Human Performance, 21(1), 27-39.

Ma, H., Zuo, Y., Li, T., \& Chen, C. L. P. (2020). Data-Driven Decision-Support System for Speaker Identification Using E-Vector System. Scientific Programming, 2020, 4748606.

MacKenzie, S. B. (2003). The dangers of poor construct conceptualization. Journal of the Academy of Marketing Science, 31, 323-326.

Margetts, H., John, P., Hale, S., \& Yasseri, T. (2015). Political turbulence: How social media shape collective action: Princeton University Press.

Martin, J., Rychlowska, M., Wood, A., \& Niedenthal, P. (2017). Smiles as multipurpose social signals. Trends in Cognitive Sciences, 21(11), 864-877.

McNeish, D., \& Kelley, K. (2018). Fixed effects models versus mixed effects models for clustered data: Reviewing the approaches, disentangling the differences, and making recommendations. Psychological Methods, 24(1), 20-35.

Mehrabian, A., \& Wiener, M. (1967). Decoding of inconsistent communications. Journal of Personality and Social Psychology, 6(1), 109.

Meslec, N., Curseu, P., Fodor, O. C., \& Kenda, R. (2020). Effects of charismatic leadership and rewards on individual performance. The Leadership Quarterly.

Milgram, S. (1963). Behavioral-Study of Obedience. Journal of Abnormal Psychology, 67(4), 371-\&.

Mio, J. S., Riggio, R. E., Levin, S., \& Reese, R. (2005). Presidential leadership and charisma: The effects of metaphor. The Leadership Quarterly, 16(2), 287-294.

Mundlak, Y. (1978). Pooling of Time-Series and Cross-Section Data. Econometrica, 46(1), 6985.

Nguyen, T. (2014). You Don't Say? Body Language Speaks Volumes More than Words. Entrepreneur, November, 24.

Pan, X., Yan, E., \& Hua, W. (2016). Science communication and dissemination in different cultures: An analysis of the audience for TED videos in China and abroad. Journal of the Association for Information Science and Technology, 67(6), 1473-1486.

Phang, C. W., Zhang, C., \& Sutanto, J. (2013). The influence of user interaction and participation in social media on the consumption intention of niche products. Information \& Management, 50(8), 661-672.

Podsakoff, P. M., MacKenzie, S. B., \& Bommer, W. H. (1996). Transformational leader behaviors and substitutes for leadership as determinants of employee satisfaction, commitment, trust, and organizational citizenship behaviors. Journal of Management, 22(2), 259-298.

Podsakoff, P. M., MacKenzie, S. B., Lee, J.-Y., \& Podsakoff, N. P. (2003). Common method biases in behavioral research: A critical review of the literature and recommended remedies. Journal of Applied Psychology, 89(5), 879-903. 
Podsakoff, P. M., MacKenzie, S. B., Moorman, R. H., \& Fetter, R. (1990). Transformational leader behaviors and their effects on follower's trust in leader, satisfaction, and organizational citizenship behaviors. The Leadership Quarterly, 1(2), 107-142.

Raven, B. H. (1993). The bases of power: Origins and recent developments. Journal of social issues, 49(4), 227-251.

Ree, M. J., \& Carretta, T. R. (2006). The role of measurement error in familiar statistics. Organizational Research Methods, 9, 99-112.

Reh, S., Van Quaquebeke, N., \& Giessner, S. R. (2017). The aura of charisma: A review on the embodiment perspective as signaling. The Leadership Quarterly, 28(4), 486-507.

Rhodes, G., Proffitt, F., Grady, J. M., \& Sumich, A. (1998). Facial symmetry and the perception of beauty. Psychonomic Bulletin \& Review, 5(4), 659-669.

Rush, M. C., Thomas, J. C., \& Lord, R. G. (1977). Implicit Leadership Theory: A Potential Threat to the Internal Validity of Leader Behavior Questionnaires. Organizational Behavior and Human Performance, 20, 93-110.

Sajons, G. B. (2020). Estimating the causal effect of measured endogenous variables: A tutorial on experimentally randomized instrumental variables. The Leadership Quarterly, 101348.

Sanderson, E., \& Windmeijer, F. (2016). A weak instrument F-test in linear IV models with multiple endogenous variables. Journal of Econometrics, 190(2), 212-221.

Sanger-Katz, M. (2020). On Coronavirus, Americans Still Trust the Experts. https://www.nytimes.com/2020/06/27/upshot/coronavirus-americans-trust-experts.html( Retrievied 13 July 2020).

Sayare, S. (2020). He Was a Science Star. Then He Promoted a Questionable Cure for Covid-19. https://www.nytimes.com/2020/05/12/magazine/didier-raoult-hydroxychloroquine.html( Retrievied 5 July 2020).

Scherbaum, C. A., \& Ferreter, J. M. (2009). Estimating Statistical Power and Required Sample Sizes for Organizational Research Using Multilevel Modeling. Organizational Research Methods, 12(2), 347-367.

Shamir, B., House, R. J., \& Arthur, M. B. (1993). The motivational effects of charismatic leadership: A self-concept based theory. Organization Science, 4(4), 577-594.

Shils, E. (1965). Charisma, Order, and Status. American Sociological Review, 30(2), 199-213.

Sieweke, J., \& Santoni, S. (2020). Natural experiments in leadership research: An introduction, review, and guidelines. The Leadership Quarterly, 31(1), 101338.

Specter, M. (2020). How Anthony Fauci Became America's Doctor. The New Yorker. Archived from the original on April 13, 2020(Retrieved 28 June 2020.).

Spence, M. (2002). Signaling in Retrospect and the Informational Structure of Markets. The American Economic Review, 92(3), 434-459.

StataCorp. (2017). Stata Statistical Software: Release 15. College Station, TX: StataCorp LP.

Stracqualursi, V. (2019). Trump mocks teenage climate activist Greta Thunberg. . CNN(Retrieved 28 June 2020).

Taggar, S., Hackett, R., \& Saha, S. (1999). Leadership emergence in autonomous work teams: antecedents and outcomes. Personnel psychology, 52.

Thibodeau, P. H., Hendricks, R. K., \& Boroditsky, L. (2017). How linguistic metaphor scaffolds reasoning. Trends in Cognitive Sciences, 21(11), 852-863.

Thorp, H. H. (2020). Persuasive words are not enough. Science translational medicine, $368(6498), 1405$.

Todorov, A. (2017). Face Value: The Irresistible Influence of First Impressions: Princeton University Press. 
Todorov, A., Olivola, C. Y., Dotsch, R., \& Mende-Siedlecki, P. (2015). Social Attributions from Faces: Determinants, Consequences, Accuracy, and Functional Significance. Annual Review of Psychology, 66, 519-545.

Toubia, O., \& Stephen, A. T. (2013). Intrinsic vs. image-related utility in social media: Why do people contribute content to twitter? Marketing Science, 32(3), 368-392.

Towler, A. J. (2003). Effects of charismatic influence training on attitudes, behavior, and performance. Personnel psychology, 56(2), 363 - 381.

Tskhay, K. O., Zhu, R., \& Rule, N. O. (2017). Perceptions of charisma from thin slices of behavior predict leadership prototypicality judgments. The Leadership Quarterly, 28(4), 555-562.

Tskhay, K. O., Zhu, R., Zou, C., \& Rule, N. O. (2018). Charisma in everyday life: Conceptualization and validation of the General Charisma Inventory. Journal of Personality and Social Psychology, 114(1), 131.

van Knippenberg, D., \& Sitkin, S. B. (2013). A critical assessment of charismatictransformational leadership research: Back to the drawing board? The Academy of Management Annals, 7(1), 1-60.

Wasielewski. (1985). The emotional basis of charisma. Symbolic interaction, 8(2), 207-222.

Weber, M. (1947). The theory of social and economic organization (T. Parsons, Trans.). New York: The Free Press.

Weber, M. (1968). On charisma and institutional building. Chicago: The University of Chicago Press.

Willner, A. R. (1984). The spellbinders: Charismatic political leadership. New Haven: CT.: Yale University Press.

Wooldridge, J. M. (2010). Econometric Analysis of Cross Section and Panel Data (2nd ed.). Cambridge, MA: MIT Press.

Yammarino, F. J., Cheong, M., Kim, J., \& Tsai, C.-Y. (2020). Is leadership more than "I like my boss"? Research in Personnel \& Human Resources Management, 38, 1-55.

Yukl, G. A. (1999). An evaluation of conceptual weaknesses in transformational and charismatic leadership theories. The Leadership Quarterly, 10(2), 285-305.

Zahavi, A. (1977). The cost of honesty. Journal of Theoretical Biology, 67(3), 603-605.

Zahavi, A. (1981). Natural selection, sexual selection and the selection of signals. Evolution today, 133-138.

Zebrowitz, L. A. (1997). Reading faces: Window to the soul? : Westview Press.

Zebrowitz, L. A. (2017). First Impressions From Faces. Current Directions in Psychological Science, 26(3), 237-242.

Zebrowitz, L. A., \& Montepare, J. M. (2008). Social psychological face perception: Why appearance matters. Social and personality psychology compass, 2(3), 1497-1517. 
TABLE 1: Definitions and operationalizations of charisma

\begin{tabular}{|c|c|c|c|c|}
\hline Element of definition & Example works & $\begin{array}{l}\text { Typical } \\
\text { operationalization }\end{array}$ & $\begin{array}{l}\text { Useful for causal } \\
\text { explanations }\end{array}$ & Implications for training \\
\hline $\begin{array}{l}\text { Gift, ability, extraordinary } \\
\text { quality }\end{array}$ & $\begin{array}{l}\text { (Etzioni, 1961; Shils, } \\
\text { 1965; Weber, 1947) }\end{array}$ & $\begin{array}{l}\text { Historical cases; } \\
\text { hermeneutic } \\
\text { analysis }\end{array}$ & No; not scientific & None \\
\hline $\begin{array}{l}\text { Defined in terms of } \\
\text { emotional, symbolic, values- } \\
\text { based signaling }\end{array}$ & $\begin{array}{l}\text { (Antonakis, et al., 2011, } \\
\text { 2012; Frese, et al., 2003; } \\
\text { Howell \& Frost, 1989; } \\
\text { Meslec, et al., 2020; } \\
\text { Towler, 2003) }\end{array}$ & $\begin{array}{l}\text { Experimental } \\
\text { manipulation }\end{array}$ & Yes & $\begin{array}{l}\text { Yes; specific tactics are } \\
\text { trainable }\end{array}$ \\
\hline
\end{tabular}

TABLE 2: Correlation Matrix of Key Variables (Study 1) 


\begin{tabular}{|c|c|c|c|c|c|c|c|c|c|c|c|c|c|c|c|c|c|c|c|}
\hline & Mean & S.D. & 1 & 2 & 3 & 4 & 5 & 6 & 7 & 8 & 9 & 10 & 11 & 12 & 13 & 14 & 15 & 16 & 17 \\
\hline 1. Views & $1.64 \mathrm{E}+06$ & $3.22 \mathrm{E}+06$ & & & & & & & & & & & & & & & & & \\
\hline 2. Inspiring & .18 & .10 & .18 & & & & & & & & & & & & & & & & \\
\hline 3. Persuasive & .09 & .07 & -.04 & .10 & & & & & & & & & & & & & & & \\
\hline 4. Male & .62 & .49 & -.18 & -.16 & .07 & & & & & & & & & & & & & & \\
\hline 5. Attractive & 4.11 & 1.10 & .13 & .12 & -.09 & -.33 & & & & & & & & & & & & & \\
\hline 6. Wearing red & .11 & .31 & .05 & -.14 & .03 & -.11 & .03 & & & & & & & & & & & & \\
\hline 7. Verbal charisma A & 44.57 & 25.00 & .21 & .21 & .26 & .11 & -.15 & -.18 & & & & & & & & & & & \\
\hline 8. Verbal charisma B & 36.40 & 21.06 & .21 & .18 & .28 & .10 & -.17 & -.13 & .92 & & & & & & & & & & \\
\hline 9. Verbal charisma C & 28.76 & 15.93 & .15 & .16 & .32 & .10 & -.16 & -.13 & .88 & .88 & & & & & & & & & \\
\hline 10. Gestures A & 1.43 & 1.04 & .30 & .09 & -.03 & -.15 & .18 & .00 & .17 & .17 & .17 & & & & & & & & \\
\hline 11. Gestures B & 1.37 & .74 & .18 & .14 & .01 & .00 & .06 & -.04 & .24 & .24 & .19 & .69 & & & & & & & \\
\hline 12. Pitch & 185.99 & 107.11 & .06 & .05 & .07 & -.28 & .02 & .03 & .06 & .14 & .13 & .28 & .17 & & & & & & \\
\hline 13. Pitch SD & 51.10 & 16.41 & .11 & .04 & -.04 & -.37 & .12 & .08 & -.06 & -.08 & -.03 & .28 & .21 & .25 & & & & & \\
\hline 14. Intense & 70.32 & 4.20 & .04 & .05 & -.06 & .05 & .08 & .00 & .17 & .09 & .18 & -.04 & -.09 & .03 & .01 & & & & \\
\hline 15. Intense SD & 13.27 & 5.07 & -.03 & .07 & .01 & .05 & -.02 & .18 & -.12 & -.10 & -.10 & -.06 & -.09 & -.02 & -.07 & .00 & & & \\
\hline 16. Log GDP & 10.71 & .57 & .06 & -.07 & -.04 & -.05 & .10 & -.05 & .14 & .13 & .15 & .04 & .08 & .02 & .15 & .02 & -.05 & & \\
\hline 17. Log Pop & 18.81 & 1.07 & .07 & .05 & -.13 & -.02 & -.04 & .00 & .12 & .10 & .07 & .00 & .00 & .05 & .05 & .21 & .00 & -.09 & \\
\hline 18. Wikipedia & 2672.00 & 4772.39 & .06 & .17 & .19 & .13 & -.04 & -.05 & .22 & .20 & .22 & -.05 & -.03 & -.10 & -.05 & .13 & -.05 & .06 & .06 \\
\hline 19. TEDx & .19 & .39 & .00 & -.06 & .04 & -.13 & .02 & .04 & -.05 & -.02 & .01 & -.07 & .01 & .17 & .03 & -.07 & -.03 & .07 & -.09 \\
\hline 20. Minutes & 13.82 & 5.32 & .14 & .05 & .18 & .10 & -.12 & -.09 & .74 & .71 & .68 & .08 & .06 & .00 & .00 & .15 & -.12 & .10 & .06 \\
\hline 21. Months & 58.46 & 28.09 & -.02 & -.10 & -.01 & .24 & -.18 & -.07 & .38 & .40 & .34 & -.06 & -.01 & -.13 & -.19 & .04 & -.08 & .07 & .18 \\
\hline 22. Months ${ }^{2}$ & 4203.66 & 3641.70 & -.04 & -.08 & -.04 & .25 & -.17 & -.06 & .39 & .40 & .35 & -.07 & -.03 & -.15 & -.18 & .15 & -.07 & .06 & .19 \\
\hline
\end{tabular}

continued

$\begin{array}{llll}18 & 19 & 20 & 21\end{array}$ 


\begin{tabular}{lllll}
\hline 1. Views & & & \\
2. Inspiring & & & \\
3. Persuasive & & & \\
4. Male & & & \\
5. Attractive & & & \\
6. Wearing red & & & \\
7. Charisma A & & & \\
8. Charisma B & & & \\
9. Charisma C & & & \\
10. Gestures A & & & \\
11. Gestures B & & & & \\
12. Pitch & & & & \\
13. Pitch SD & & & & \\
14. Intense & & & & \\
15. Intense SD & & & & \\
16. Log GDP & & & & \\
17. Log Pop & & & & \\
18. Wikipedia & & & & \\
19. TEDx & -.13 & & & \\
20. Minutes & .30 & -.02 & & \\
21. Months & .21 & -.25 & .34 & \\
22. Months & .24 & -.26 & .36 & .98 \\
& & & & \\
& & & &
\end{tabular}

Note. $n=240$; correlations greater than $|.16|$ are significant at $p<.01$; correlations greater than $|.12|$ are significant at $p<.05$; correlations greater than .10 are significant at $p<.10$. 
TABLE 3: Estimates predicting views (Study 1)

\begin{tabular}{|c|c|c|c|c|c|c|c|}
\hline Variables & $\begin{array}{c}(1) \\
\text { Views }\end{array}$ & $\begin{array}{c}(2) \\
\text { Views }\end{array}$ & $\begin{array}{c}(3) \\
\text { Views }\end{array}$ & $\begin{array}{c}(4) \\
\text { Views }\end{array}$ & $\begin{array}{c}(5) \\
\text { Views }\end{array}$ & $\begin{array}{c}(6) \\
\text { Views }\end{array}$ & $\begin{array}{c}(7) \\
\text { Views }\end{array}$ \\
\hline Attractive & $\frac{.23}{(3.68)}$ & $\underline{.25}^{* * *}$ & $\frac{.24 * * *}{(3.69)}$ & $\frac{.20}{(2.72)}$ & $\frac{.24 * * *}{(4.57)}$ & $\frac{.25 * * *}{(5.18)}$ & $\frac{.18}{(2.73)}^{* * *}$ \\
\hline Male & $\begin{array}{c}-.22 \\
(1.35)\end{array}$ & $\begin{array}{c}-.15 \\
(1.16)\end{array}$ & $\begin{array}{l}-.02 \\
(.12)\end{array}$ & $\begin{array}{l}-.09 \\
(.62)\end{array}$ & $\begin{array}{l}-.03 \\
(.24)\end{array}$ & $\begin{array}{l}-.00 \\
(.02)\end{array}$ & $\begin{array}{l}-.08 \\
(.61)\end{array}$ \\
\hline Wiki. page & $\begin{array}{c}.00 \\
(1.50)\end{array}$ & $\frac{.00^{*}}{(1.92)}$ & $\frac{.00}{(2.24)}$ & $\frac{.00}{(2.84)}$ & $\underline{(2.91)}^{.00 * *}$ & $\underline{(2.81)}^{.00 * *}$ & $\underline{(3.33)}^{.00 * *}$ \\
\hline Duration & $\begin{array}{c}.06 \\
(1.44)\end{array}$ & $\begin{array}{c}.00 \\
(.02)\end{array}$ & $\begin{array}{l}-.00 \\
(.04)\end{array}$ & $\begin{array}{c}.02 \\
(.49)\end{array}$ & $\begin{array}{l}-.00 \\
(.04)\end{array}$ & & \\
\hline Months old & $\begin{array}{r}.02 \\
(1.40)\end{array}$ & $\begin{array}{c}.01 \\
(.77)\end{array}$ & $\begin{array}{c}.01 \\
(.71)\end{array}$ & $\begin{array}{c}.01 \\
(1.04)\end{array}$ & $\begin{array}{c}.01 \\
(1.05)\end{array}$ & $\begin{array}{c}.01 \\
(.77)\end{array}$ & $\begin{array}{c}.01 \\
(.89)\end{array}$ \\
\hline Months old2 & $\begin{array}{c}-.00 \\
(1.45)\end{array}$ & $\begin{array}{c}-.00 \\
(1.25)\end{array}$ & $\begin{array}{c}-.00 \\
(1.35)\end{array}$ & $\begin{array}{c}-.00 * \\
(1.67)\end{array}$ & $\begin{array}{c}-.00 * \\
(1.87)\end{array}$ & $\begin{array}{c}-.00 \\
(1.36)\end{array}$ & $\begin{array}{c}-.00 \\
(1.40)\end{array}$ \\
\hline Log GDP & $\begin{array}{l}-.06 \\
(.50)\end{array}$ & $\begin{array}{l}-.10 \\
(.95)\end{array}$ & $\begin{array}{l}-.09 \\
(.84)\end{array}$ & $\begin{array}{l}-.09 \\
(.79)\end{array}$ & $\begin{array}{c}-.13 \\
(1.38)\end{array}$ & $\begin{array}{c}-.15 \\
(1.62)\end{array}$ & $\begin{array}{c}-.10 \\
(1.10)\end{array}$ \\
\hline Log Pop. & $\begin{array}{c}.02 \\
(.22)\end{array}$ & $\begin{array}{l}-.02 \\
(.36)\end{array}$ & $\begin{array}{c}.01 \\
(.12)\end{array}$ & $\begin{array}{l}-.01 \\
(.10)\end{array}$ & $\begin{array}{l}-.02 \\
(.32)\end{array}$ & $\begin{array}{l}-.03 \\
(.59)\end{array}$ & $\begin{array}{l}-.02 \\
(.39)\end{array}$ \\
\hline TEDx & $\begin{array}{l}-.31 \\
(.90)\end{array}$ & $\frac{-.59}{(2.46)}$ & $\frac{-.66}{(3.26)}^{* * *}$ & $\frac{-.62}{(2.41)}$ & $\frac{-.73}{(3.80)}^{* * *}$ & $\frac{-.65^{* * *}}{(3.21)}$ & ${\frac{-.55^{* * *}}{(2.73)}}^{* *}$ \\
\hline Verb. charisma & & $\begin{array}{l}\underline{.02}^{*} * * * \\
(2.97)\end{array}$ & $\underline{.02}_{(3.01)}^{.0 * *}$ & $\underline{.02}^{.0 *}$ & & $\frac{.02 * * *}{(6.87)}$ & $\underline{(3.94)}^{.01 * *}$ \\
\hline Pitch mean (A) & & & $\begin{array}{c}.01 \\
(.96)\end{array}$ & $\begin{array}{c}.01 \\
(1.07)\end{array}$ & $\begin{array}{c}.01 \\
(.83)\end{array}$ & $\begin{array}{l}.01 * * \\
(2.03)\end{array}$ & $\begin{array}{l}.01 * * \\
(2.01)\end{array}$ \\
\hline Pitch SD (B) & & & $\begin{array}{c}.03 \\
(1.64)\end{array}$ & $\begin{array}{c}.03 * \\
(1.74)\end{array}$ & $\begin{array}{c}.03 * \\
(1.65)\end{array}$ & $\begin{array}{l}.05^{* * *} \\
(2.69)\end{array}$ & $\begin{array}{l}.04 * * * \\
(2.65)\end{array}$ \\
\hline $\mathrm{A} * \mathrm{~B}$ & & & $\begin{array}{c}-.00 \\
(1.11)\end{array}$ & $\begin{array}{c}-.00 \\
(1.36)\end{array}$ & $\begin{array}{c}-.00 \\
(1.15)\end{array}$ & $\begin{array}{l}-.00 * * \\
(2.29)\end{array}$ & $\begin{array}{l}-.00 * * \\
(2.41)\end{array}$ \\
\hline Intense mean $(\mathrm{C})$ & & & $\begin{array}{l}-.16^{* * *} \\
(3.17)\end{array}$ & $\begin{array}{l}-.19 * * * \\
(2.79)\end{array}$ & $\begin{array}{l}-.22 * * * \\
(4.24)\end{array}$ & $\begin{array}{l}-.23 * * * \\
(4.22)\end{array}$ & $\begin{array}{l}-.20 * * * \\
(3.15)\end{array}$ \\
\hline Intense SD (D) & & & $\frac{-.92}{(3.06)}$ & $\frac{-1.17}{(3.27)}$ & $\frac{-1.30}{(4.42)}$ & $\frac{-1.34}{(4.15)}$ & $\frac{-1.19}{(3.49)}$ \\
\hline $\mathrm{C} * \mathrm{D}$ & & & $\begin{array}{l}.01 * * * \\
(3.11)\end{array}$ & $\begin{array}{l}.02 * * * \\
(3.24)\end{array}$ & $\begin{array}{l}.02 * * * \\
(4.35)\end{array}$ & $\begin{array}{l}.02 * * * \\
(4.09)\end{array}$ & $\begin{array}{l}.02 * * * \\
(3.47)\end{array}$ \\
\hline Gesturing & & & & $\begin{array}{c}.13 \\
(.75)\end{array}$ & & & $\begin{array}{r}.20 \\
(1.46)\end{array}$ \\
\hline Charisma index & & & & & $\frac{.02}{(5.61)}$ & & \\
\hline Constant & $\begin{array}{l}12.33 * * * \\
(4.17)\end{array}$ & $\begin{array}{l}14.02 * * * \\
(6.52)\end{array}$ & $\begin{array}{l}23.58 * * * \\
(5.18)\end{array}$ & $\begin{array}{l}26.47 * * * \\
(3.96)\end{array}$ & $\begin{array}{l}29.72 * * * \\
(6.59)\end{array}$ & $\begin{array}{l}29.64 * * * \\
(6.24)\end{array}$ & $\begin{array}{l}26.36 * * * \\
(4.72)\end{array}$ \\
\hline $\begin{array}{l}\text { Pseudo R-squared } \\
\text { (McFadden) }\end{array}$ & .58 & 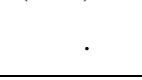 & $x^{2}-2$ & $\cdot$ & & & \\
\hline
\end{tabular}


TABLE 4a: Estimates predicting adjective inspiring (Study 1)

\begin{tabular}{|c|c|c|c|c|c|}
\hline Variables & $\begin{array}{c}(1) \\
\text { Inspiring }\end{array}$ & $\begin{array}{c}(2) \\
\text { Inspiring }\end{array}$ & $\begin{array}{c}(3) \\
\text { Inspiring }\end{array}$ & $\begin{array}{c}(4) \\
\text { Inspiring }\end{array}$ & $\begin{array}{c}(5) \\
\text { Inspiring }\end{array}$ \\
\hline \multirow[t]{2}{*}{ Attractive } & -.01 & .01 & -.00 & -.01 & -.00 \\
\hline & $(.21)$ & (.16) & $(.02)$ & $(.21)$ & $(.08)$ \\
\hline \multirow[t]{2}{*}{ Male } & $-.27 * *$ & $-.26 * *$ & $-.28 * *$ & $-.29 * * *$ & $-.28 * * *$ \\
\hline & $(2.31)$ & $(2.52)$ & $(2.57)$ & $(2.58)$ & $(2.60)$ \\
\hline \multirow[t]{2}{*}{ Wiki page } & $.00 * * *$ & $.00 * * *$ & $.00 * * *$ & $.00 * * *$ & $.00^{* * * *}$ \\
\hline & $(3.15)$ & $(3.20)$ & $(3.07)$ & $(3.05)$ & $(3.06)$ \\
\hline \multirow[t]{2}{*}{ Duration } & -.00 & -.01 & -.03 & -.03 & -.03 \\
\hline & (.19) & $(.96)$ & $(1.56)$ & $(1.61)$ & $(1.58)$ \\
\hline \multirow[t]{2}{*}{ Months old } & -.01 & -.01 & -.01 & -.01 & .01 \\
\hline & $(.89)$ & $(.87)$ & $(.94)$ & $(.95)$ & (.94) \\
\hline \multirow[t]{2}{*}{ Months old 2} & .00 & .00 & .00 & .00 & .00 \\
\hline & $(.41)$ & $(.15)$ & $(.38)$ & (.39) & $(.38)$ \\
\hline \multirow[t]{2}{*}{ Log GDP } & $-.14 *$ & $-.17 * *$ & $-.13 *$ & $-.13 *$ & $-.13 *$ \\
\hline & $(1.77)$ & $(2.37)$ & (1.95) & $(1.73)$ & (1.93) \\
\hline \multirow[t]{2}{*}{ Log Population } & .03 & .02 & .02 & .02 & .02 \\
\hline & $(.61)$ & (.44) & $(.47)$ & $(.54)$ & $(.50)$ \\
\hline \multirow[t]{2}{*}{ TEDx } & -.22 & -.20 & -.18 & -.16 & -.17 \\
\hline & $(1.58)$ & (1.64) & $(1.37)$ & (1.18) & (1.33) \\
\hline \multirow[t]{2}{*}{ Verbal charisma } & & $.01 * * *$ & $.01 * * *$ & $.01 * * *$ & \\
\hline & & $(3.60)$ & $(3.22)$ & $(2.70)$ & \\
\hline \multirow[t]{2}{*}{ Pitch mean } & & & .00 & .00 & .00 \\
\hline & & & $(.43)$ & (.38) & $(.41)$ \\
\hline \multirow[t]{2}{*}{ Pitch SD } & & & .01 & .01 & .01 \\
\hline & & & (.63) & (.59) & $(.62)$ \\
\hline \multirow[t]{2}{*}{ Pitch mean* Pitch SD } & & & -.00 & -.00 & -.00 \\
\hline & & & $(.52)$ & $(.53)$ & $(.52)$ \\
\hline \multirow[t]{2}{*}{ Intensity mean } & & & .04 & .05 & .04 \\
\hline & & & $(.83)$ & $(.90)$ & $(.86)$ \\
\hline \multirow[t]{2}{*}{ Intensity SD } & & & .27 & .30 & .28 \\
\hline & & & $(1.11)$ & $(1.16)$ & $(1.14)$ \\
\hline \multirow[t]{2}{*}{ Intensity mean* Intensity SD } & & & -.00 & -.00 & -.00 \\
\hline & & & $(.98)$ & $(1.03)$ & $(1.01)$ \\
\hline \multirow[t]{2}{*}{ Gesturing } & & & & .04 & \\
\hline & & & & $(.44)$ & \\
\hline \multirow[t]{2}{*}{ Charisma index } & & & & & $.01 * * *$ \\
\hline & & & & & $(3.44)$ \\
\hline \multirow[t]{2}{*}{ Constant } & .15 & .47 & -3.61 & -4.12 & -3.75 \\
\hline & $(.10)$ & $(.33)$ & $(.84)$ & $(.91)$ & $(.88)$ \\
\hline R-squared & .28 & .33 & .35 & .35 & .35 \\
\hline
\end{tabular}

Robust $\mathrm{z}$-statistics in parentheses; ${ }^{* * *} p<.01,{ }^{* *} p<.05, * p<.10$; Note. All controls included in all models. Model 1 is estimated with OLS regression; Models 2 to 5 estimated with two-stage least squares regression. Because the dependent variables are bounded they are logit transformed. Models 4 and 5 provided as a robustness checks and for interest only. Estimates are unstandardized. $n=240$ observations. 
TABLE 4b: Estimates predicting adjective persuasive (Study 1)

\begin{tabular}{|c|c|c|c|c|c|}
\hline Variables & $\begin{array}{c}\text { (5) } \\
\text { Persuasive }\end{array}$ & $\begin{array}{c}\text { (6) } \\
\text { Persuasive }\end{array}$ & $\begin{array}{c}(7) \\
\text { Persuasive }\end{array}$ & $\begin{array}{c}(8) \\
\text { Persuasive }\end{array}$ & $\begin{array}{c}\text { (9) } \\
\text { Persuasive }\end{array}$ \\
\hline Attractive & $\begin{array}{l}-.05 \\
(.83)\end{array}$ & $\begin{array}{l}-.03 \\
(.49)\end{array}$ & $\begin{array}{l}-.04 \\
(.70)\end{array}$ & $\begin{array}{c}.01 \\
(.25)\end{array}$ & $\begin{array}{l}-.04 \\
(.80)\end{array}$ \\
\hline Male & $\begin{array}{l}-.03 \\
(.25)\end{array}$ & $\begin{array}{l}-.02 \\
(.16)\end{array}$ & $\begin{array}{l}-.07 \\
(.51)\end{array}$ & $\begin{array}{l}-.01 \\
(.11)\end{array}$ & $\begin{array}{l}-.07 \\
(.53)\end{array}$ \\
\hline Wiki page & $\begin{array}{l}.00 * * \\
(2.30)\end{array}$ & $\begin{array}{l}.00 * * \\
(2.57)\end{array}$ & $\begin{array}{l}.00 * * \\
(2.44)\end{array}$ & $\begin{array}{l}.00 * * \\
(1.99)\end{array}$ & $\begin{array}{l}.00^{* *} \\
(2.45)\end{array}$ \\
\hline Duration & $\begin{array}{l}-.02 \\
(.53)\end{array}$ & $\begin{array}{c}-.03 \\
(1.12)\end{array}$ & $\begin{array}{c}-.04 \\
(1.29)\end{array}$ & $\begin{array}{l}-.02 \\
(.93)\end{array}$ & $\begin{array}{c}-.04 \\
(1.25)\end{array}$ \\
\hline Months old & $\begin{array}{l}.03 * * * \\
(3.14)\end{array}$ & $\begin{array}{l}.03 * * * \\
(3.42)\end{array}$ & $\begin{array}{l}.03 * * * \\
(3.17)\end{array}$ & $\begin{array}{l}.03 * * * \\
(3.25)\end{array}$ & $\begin{array}{l}.03 * * * \\
(3.16)\end{array}$ \\
\hline Months old 2 & $\begin{array}{l}-.00^{* * * *} \\
(3.75)\end{array}$ & $\begin{array}{l}-.00^{* * * *} \\
(4.16)\end{array}$ & $\begin{array}{l}-.00^{* * * *} \\
(3.63)\end{array}$ & $\begin{array}{l}-.00^{* * * *} \\
(3.81)\end{array}$ & $\begin{array}{l}-.00^{* * *} \\
(3.61)\end{array}$ \\
\hline Log GDP & $\begin{array}{l}-.02 \\
(.20)\end{array}$ & $\begin{array}{l}-.05 \\
(.58)\end{array}$ & $\begin{array}{l}-.03 \\
(.36)\end{array}$ & $\begin{array}{l}-.08 \\
(.92)\end{array}$ & $\begin{array}{l}-.03 \\
(.30)\end{array}$ \\
\hline Log Population & $\begin{array}{l}-.03 \\
(.49)\end{array}$ & $\begin{array}{l}-.04 \\
(.80)\end{array}$ & $\begin{array}{l}-.04 \\
(.68)\end{array}$ & $\begin{array}{l}-.04 \\
(.81)\end{array}$ & $\begin{array}{l}-.03 \\
(.64)\end{array}$ \\
\hline TEDx & $\begin{array}{c}.05 \\
(.35)\end{array}$ & $\begin{array}{l}.08 \\
(.58)\end{array}$ & $\begin{array}{c}.13 \\
(1.00)\end{array}$ & $\begin{array}{l}.00 \\
(.02)\end{array}$ & $\begin{array}{c}.14 \\
(1.03)\end{array}$ \\
\hline Verbal charisma & & $\begin{array}{l}.02 * * * \\
(3.68)\end{array}$ & $\begin{array}{l}.02 * * * \\
(3.43)\end{array}$ & $\begin{array}{l}.02 * * * \\
(3.74)\end{array}$ & \\
\hline Pitch mean & & & $\begin{array}{c}-.01 * \\
(1.89)\end{array}$ & $\begin{array}{c}-.01 * \\
(1.79)\end{array}$ & $\begin{array}{c}-.01 * \\
(1.90)\end{array}$ \\
\hline Pitch SD & & & $\begin{array}{l}-.02 * * \\
(2.00)\end{array}$ & $\begin{array}{c}-.02 * \\
(1.78)\end{array}$ & $\begin{array}{l}-.02 * * \\
(2.02)\end{array}$ \\
\hline Pitch mean* Pitch SD & & & $\begin{array}{r}.00 * \\
(1.95)\end{array}$ & $\begin{array}{r}.00 * \\
(1.90)\end{array}$ & $\begin{array}{r}.00 * \\
(1.96)\end{array}$ \\
\hline Intensity mean & & & $\begin{array}{c}.09 \\
(1.50)\end{array}$ & $\begin{array}{c}.05 \\
(.99)\end{array}$ & $\begin{array}{c}.09 \\
(1.58)\end{array}$ \\
\hline Intensity SD & & & $\begin{array}{c}.49 \\
(1.58)\end{array}$ & $\begin{array}{c}.33 \\
(1.12)\end{array}$ & $\begin{array}{r}.51 * \\
(1.65)\end{array}$ \\
\hline Intensity mean* Intensity SD & & & $\begin{array}{c}-.01 \\
(1.52)\end{array}$ & $\begin{array}{c}-.00 \\
(1.09)\end{array}$ & $\begin{array}{c}-.01 \\
(1.59)\end{array}$ \\
\hline Gesturing & & & & $\begin{array}{l}-.17 * * \\
(2.02)\end{array}$ & \\
\hline Charisma index & & & & & $\begin{array}{l}.01^{* * * *} \\
(3.16)\end{array}$ \\
\hline Constant & $\begin{array}{l}-3.97 * * \\
(2.18)\end{array}$ & $\begin{array}{l}-3.56^{* *} \\
(2.21)\end{array}$ & $\begin{array}{l}-9.06 * \\
(1.95)\end{array}$ & $\begin{array}{l}-6.16 \\
(1.35)\end{array}$ & $\begin{array}{l}-9.46 \\
(2.03)\end{array}$ \\
\hline R-squared & .34 & .36 & .38 & .41 & .38 \\
\hline
\end{tabular}

Robust $\mathrm{z}$-statistics in parentheses; $* * * p<.01, * * p<.05, * p<.10$; Note. All controls included in all models. Model 5 is estimated with OLS regression; Models 6 to 9 estimated with two-stage least squares regression. Because the dependent variables are bounded they are logit transformed. Models 4 and 5 provided as a robustness checks and for interest only. Estimates are unstandardized. $n=240$ observations. 
Table 5: Correlation Matrix of Key Variables (Study 2)

\begin{tabular}{|c|c|c|c|c|c|c|c|c|c|c|c|c|c|c|c|c|c|c|c|c|}
\hline Variables & Mean & S.D. & 1 & 2 & 3 & 4 & 5 & 6 & 7 & 8 & 9 & 10 & 11 & 12 & 13 & 14 & 15 & 16 & 17 & 18 \\
\hline 1. Retweets & 6.17 & 16.22 & & & & & & & & & & & & & & & & & & \\
\hline 2. Male & .76 & .42 & .02 & & & & & & & & & & & & & & & & & \\
\hline 3. Politician & .51 & .50 & -.08 & -.31 & & & & & & & & & & & & & & & & \\
\hline 4. Republican & .25 & .43 & -.02 & -.22 & .58 & & & & & & & & & & & & & & & \\
\hline 5. Followers & 16.65 & 43.47 & .48 & .16 & -.23 & -.05 & & & & & & & & & & & & & & \\
\hline 6.Charisma $\mathrm{A}_{\mathrm{F}}$ & .30 & .13 & .19 & .01 & -.12 & -.31 & .03 & & & & & & & & & & & & & \\
\hline 7.Charisma $\mathrm{B}_{\mathrm{F}}$ & .19 & .15 & .13 & .06 & .12 & -.35 & -.06 & .65 & & & & & & & & & & & & \\
\hline 8.Charisma $C_{F}$ & .21 & .11 & .05 & -.11 & .40 & .00 & -.17 & .67 & .59 & & & & & & & & & & & \\
\hline 9. Charisma A & .30 & .54 & .03 & -.00 & -.03 & -.07 & .01 & .24 & .16 & .16 & & & & & & & & & & \\
\hline 10. Charisma B & .19 & .46 & .04 & .02 & .04 & -.11 & -.02 & .21 & .32 & .19 & .54 & & & & & & & & & \\
\hline 11. Charisma C & .21 & .44 & .02 & -.03 & .10 & .00 & -.04 & .16 & .14 & .24 & .49 & .41 & & & & & & & & \\
\hline 12. @ mentions & .64 & .96 & -.09 & .05 & -.15 & -.09 & .07 & -.01 & .00 & -.11 & -.02 & .00 & -.04 & & & & & & & \\
\hline 13. Hashtags & .50 & .90 & -.02 & -.06 & .23 & .25 & -.09 & -.04 & -.04 & .12 & -.02 & -.02 & .01 & -.01 & & & & & & \\
\hline 14. Links & .53 & .52 & .09 & -.03 & .18 & .22 & -.01 & -.08 & -.08 & .01 & -.01 & -.03 & .04 & -.17 & .03 & & & & & \\
\hline 15. Press & .06 & .23 & .01 & .08 & .02 & -.05 & -.04 & -.09 & -.04 & -.07 & -.04 & -.02 & -.02 & -.06 & -.06 & .22 & & & & \\
\hline 16. Picture & .08 & .27 & -.01 & -.15 & .11 & .11 & .03 & -.07 & -.09 & -.02 & -.01 & -.01 & .00 & -.08 & .00 & .25 & -.07 & & & \\
\hline 17. Video & .03 & .18 & -.01 & -.03 & .08 & .09 & -.04 & -.01 & -.02 & .03 & .01 & .00 & .03 & -.01 & .08 & .15 & -.03 & -.04 & & \\
\hline 18. Days old & 43.98 & 25.49 & .01 & -.00 & .01 & .02 & -.05 & .07 & .02 & .05 & .02 & .02 & .04 & -.03 & -.02 & .03 & .01 & .00 & -.04 & \\
\hline 19. Retweet & .06 & .24 & -.07 & -.01 & -.02 & .00 & -.05 & .02 & .02 & -.01 & .01 & .00 & -.02 & .31 & .03 & .01 & .01 & -.04 & .04 & -.01 \\
\hline
\end{tabular}

Note. $n=2,964$ observations. Number of followers is in thousands. We do not indicate significance levels for the correlations given that the data are nested (at the $i j$ level); thus, the $t$-statistic assumption of independence of observations is violated. Subscript F denotes fixed-effects (i.e., using cluster means). 
TABLE 6: Estimates (Study 2)

\begin{tabular}{|c|c|c|c|c|c|c|}
\hline Variables & (1) & (2) & (3) & (4) & (5) & (6) \\
\hline \multicolumn{7}{|l|}{ Step 1} \\
\hline Male & $\begin{array}{c}-.46^{*} \\
(1.74)\end{array}$ & $\begin{array}{c}-.31 \\
(1.09)\end{array}$ & $\begin{array}{r}-2.19 \\
(.97)\end{array}$ & $\begin{array}{r}-1.99 \\
(.86)\end{array}$ & $\begin{array}{l}-4.60 \\
(1.35)\end{array}$ & $\begin{array}{l}-4.38 \\
(1.21)\end{array}$ \\
\hline Politician & $\begin{array}{c}.23 \\
(.59)\end{array}$ & $\begin{array}{c}.31 \\
(1.09)\end{array}$ & $\begin{array}{c}.30 \\
(.10)\end{array}$ & $\begin{array}{l}-.43 \\
(.16)\end{array}$ & $\begin{array}{l}1.49 \\
(.34)\end{array}$ & $\begin{array}{c}.25 \\
(.06)\end{array}$ \\
\hline Republican & $\frac{-1.57}{(3.77)}^{* * *}$ & $\begin{array}{c}.31 \\
(1.09)\end{array}$ & $\begin{array}{l}-5.42 * \\
(1.98)\end{array}$ & $\begin{array}{l}.18 \\
(.05)\end{array}$ & $\begin{array}{l}-1.21 * * \\
(2.49)\end{array}$ & $\begin{array}{r}-1.58 \\
(.27)\end{array}$ \\
\hline Followers & $\begin{array}{r}-.01 * \\
(1.75)\end{array}$ & $\begin{array}{c}-.01 * \\
(1.88)\end{array}$ & $\begin{array}{l}-.07 \\
(.17)\end{array}$ & $\begin{array}{l}-.07 \\
(.17)\end{array}$ & $\begin{array}{l}-.41 \\
(.74)\end{array}$ & $\begin{array}{l}-.38 \\
(.70)\end{array}$ \\
\hline Days old & $\begin{array}{c}.01 \\
(1.63)\end{array}$ & $\begin{array}{c}.01 * \\
(1.80)\end{array}$ & $\begin{array}{c}.07 \\
(1.63)\end{array}$ & $\begin{array}{r}.07 * \\
(1.67)\end{array}$ & $\begin{array}{c}.10 \\
(1.46)\end{array}$ & $\begin{array}{c}.10 \\
(1.49)\end{array}$ \\
\hline Days old ${ }^{2}$ & $\begin{array}{c}-.00 \\
(1.22)\end{array}$ & $\begin{array}{c}-.00 \\
(1.34)\end{array}$ & $\begin{array}{c}-.00 \\
(1.20)\end{array}$ & $\begin{array}{c}-.00 \\
(1.22)\end{array}$ & $\begin{array}{l}-.00 \\
(.95)\end{array}$ & $\begin{array}{l}-.00 \\
(.97)\end{array}$ \\
\hline Followers $_{\mathrm{F}}$ & $\frac{.03}{(4.44)}{ }^{* * *}$ & $\frac{.03}{(4.54)}^{* * *}$ & $\begin{array}{c}.26 \\
(.72)\end{array}$ & $\begin{array}{c}.25 \\
(.66)\end{array}$ & $\begin{array}{c}.68 \\
(1.27)\end{array}$ & $\begin{array}{c}.63 \\
(1.18)\end{array}$ \\
\hline Days old & $\begin{array}{l}-.00 \\
(.00)\end{array}$ & $\begin{array}{c}-.12 * \\
(1.89)\end{array}$ & $\begin{array}{l}-.01 \\
(.01)\end{array}$ & $\begin{array}{l}-.44 \\
(.85)\end{array}$ & $\begin{array}{l}-.03 \\
(.04)\end{array}$ & $\begin{array}{l}-.80 \\
(.98)\end{array}$ \\
\hline Days old ${ }_{F}^{2}$ & $\begin{array}{c}.00 \\
(.74)\end{array}$ & $\left(^{.00} \frac{.00}{29}^{*}\right)$ & $\begin{array}{l}.00 \\
(.17)\end{array}$ & $\begin{array}{l}.00 \\
(.55)\end{array}$ & $\begin{array}{l}.00 \\
(.21)\end{array}$ & $\begin{array}{c}.01 \\
(.70)\end{array}$ \\
\hline $\begin{array}{l}\text { Controls } \\
\text { Controls }_{\mathrm{F}}\end{array}$ & $\begin{array}{l}\text { Incl. } \\
\text { Incl. }\end{array}$ & $\begin{array}{l}\text { Incl. } \\
\text { Incl. }\end{array}$ & $\begin{array}{l}\text { Incl. } \\
\text { Incl. }\end{array}$ & $\begin{array}{l}\text { Incl. } \\
\text { Incl. }\end{array}$ & $\begin{array}{l}\text { Incl. } \\
\text { Incl. }\end{array}$ & $\begin{array}{l}\text { Incl. } \\
\text { Incl. }\end{array}$ \\
\hline Constant & $\begin{array}{l}4.76^{* * *} \\
(4.18)\end{array}$ & $\begin{array}{l}4.89 * * * \\
(4.42)\end{array}$ & $\begin{array}{c}9.37 \\
(1.21)\end{array}$ & $\begin{array}{c}8.48 \\
(1.14)\end{array}$ & $\begin{array}{l}24.01 * \\
(1.74)\end{array}$ & $\begin{array}{c}23.77 * \\
(1.69)\end{array}$ \\
\hline Step 2 & & & & & & \\
\hline Charisma $_{F}$ & & 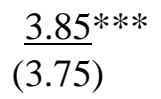 & & $\begin{array}{l}31.82 * * \\
(2.53)\end{array}$ & & $\begin{array}{l}48.22 * * * \\
(2.61)\end{array}$ \\
\hline Charisma & & $\begin{array}{l}-.01 \\
(.21)\end{array}$ & & $\begin{array}{l}-.00 \\
(.01)\end{array}$ & & $\begin{array}{c}.34 \\
(.35)\end{array}$ \\
\hline R-squared & & & .35 & .36 & & \\
\hline
\end{tabular}

Cluster-robust z-statistics in parentheses; $* * * p<.01, * * p<.05, * p<.10$; Subscript F denotes fixedeffect (using cluster mean). Model 1 estimated with a Poisson regression; Model 2 estimated with an instrumental variable Poisson regression. Models 3 estimated with OLS. Model 4 estimated with two-stage least squares. Model 5 estimated with a Tobit (including upper, 100, and lower, 0 limits). Model 6 estimated with an instrumental-variable Tobit estimator. Estimates are unstandardized. $n=$ 2,964 , clustered at $N=60$. Given that Poisson estimates are exponentiated and not directly interpreted, underlined estimates indicate average marginal effects that are significant at $p=.05$ or less. 


\section{FIGURE 1: Distribution of Charisma Scores of TED speakers}
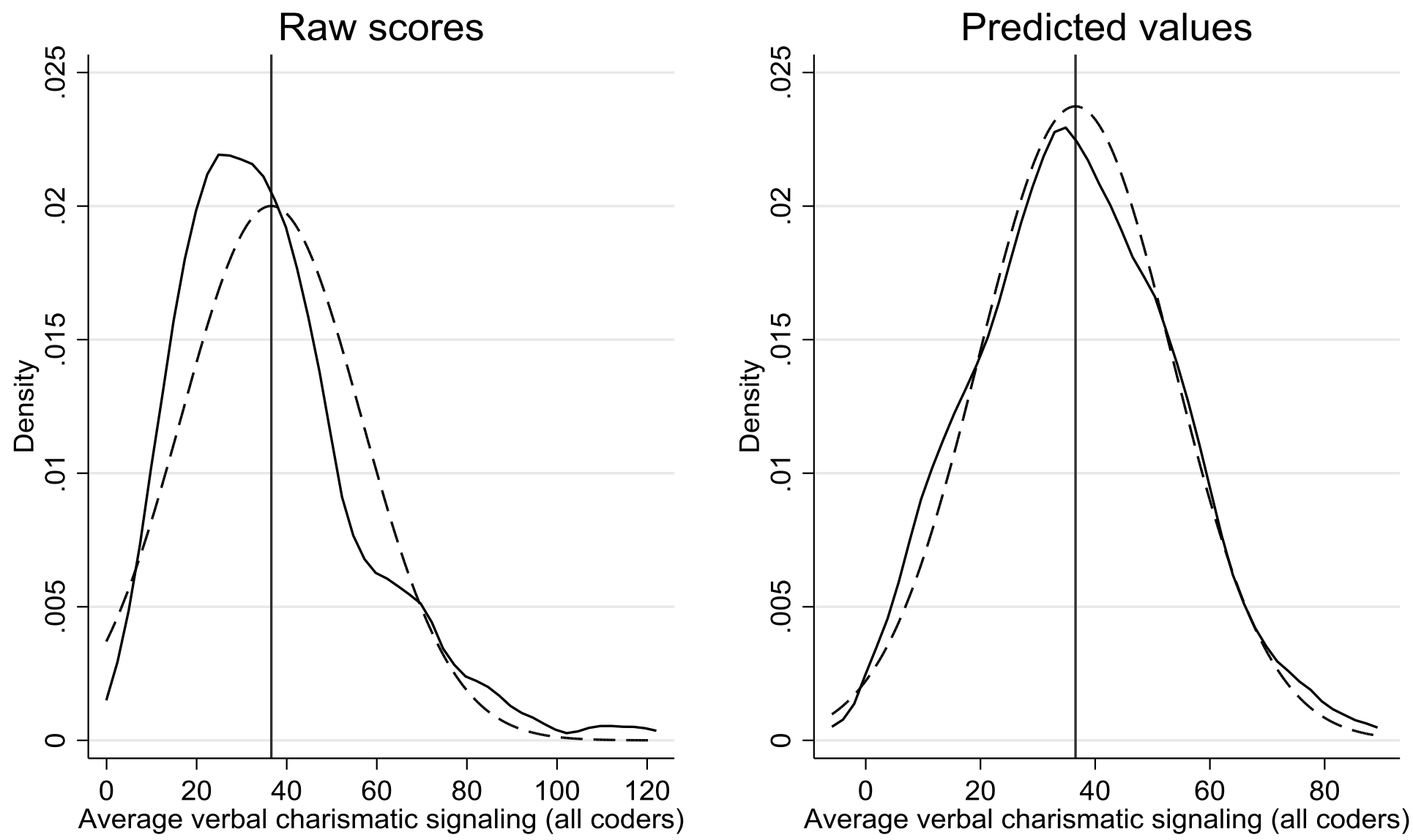

$$
\begin{array}{ll}
- & \text { Kernel density estimate } \\
---- & \text { Normal density }
\end{array}
$$

kernel $=$ epanechnikov, bandwidth $=5.3877$

Average verbal charismatic signaling (all coders)

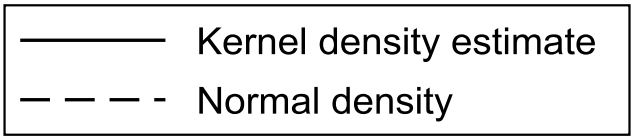

kernel $=$ epanechnikov, bandwidth $=5.0552$

Note: Vertical line corresponds to the mean: Graph on right is the predicted value conditioned on all the control variables. 


\section{FIGURE 2: Effects of Charismatic Signaling Tactics on TED views}

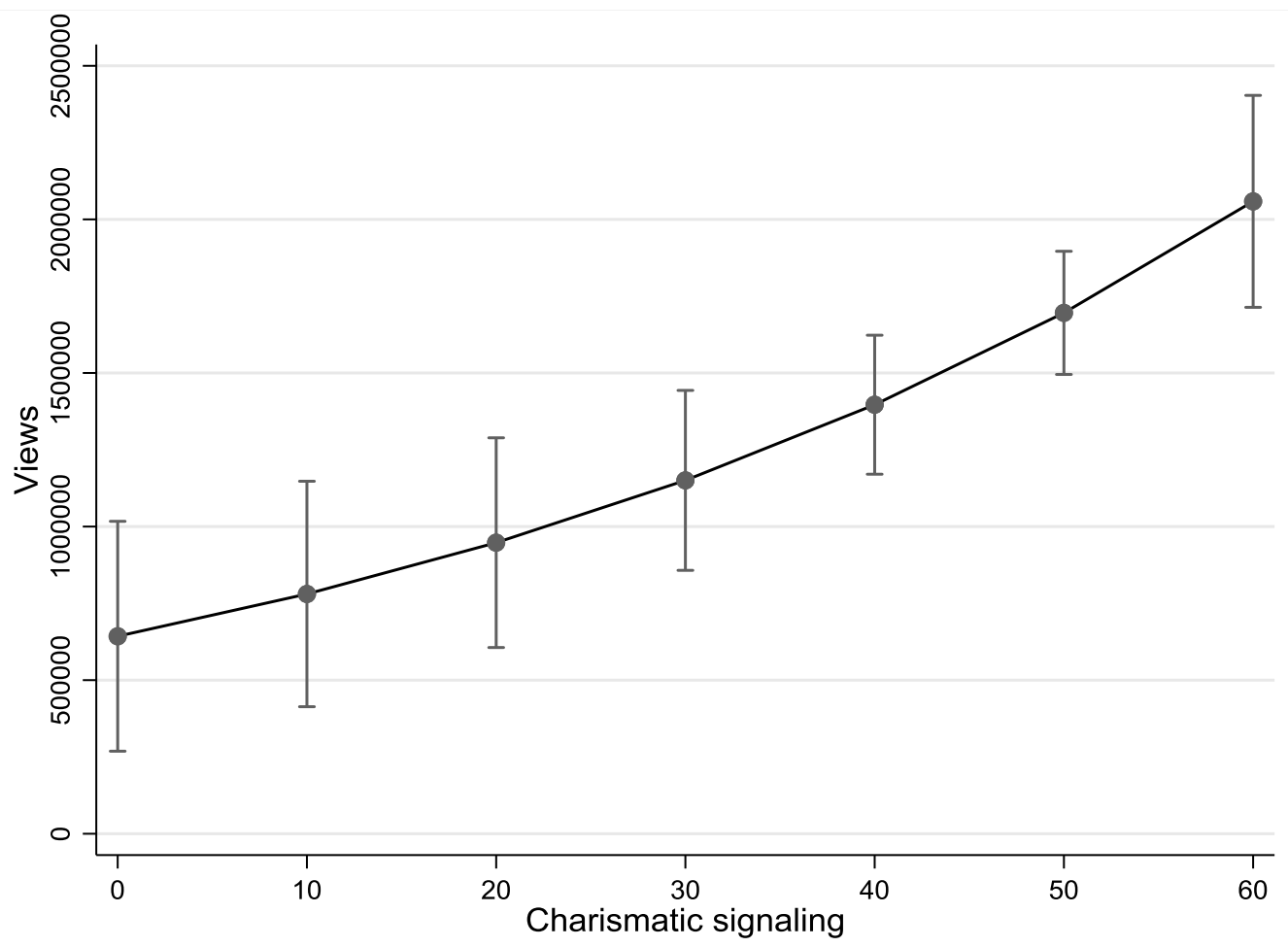

Note: Marginal effects calculated from Model 3 estimates in Table 2a. 


\section{FIGURE 3: Effects of Charismatic Signaling Fixed Effects on Retweets}

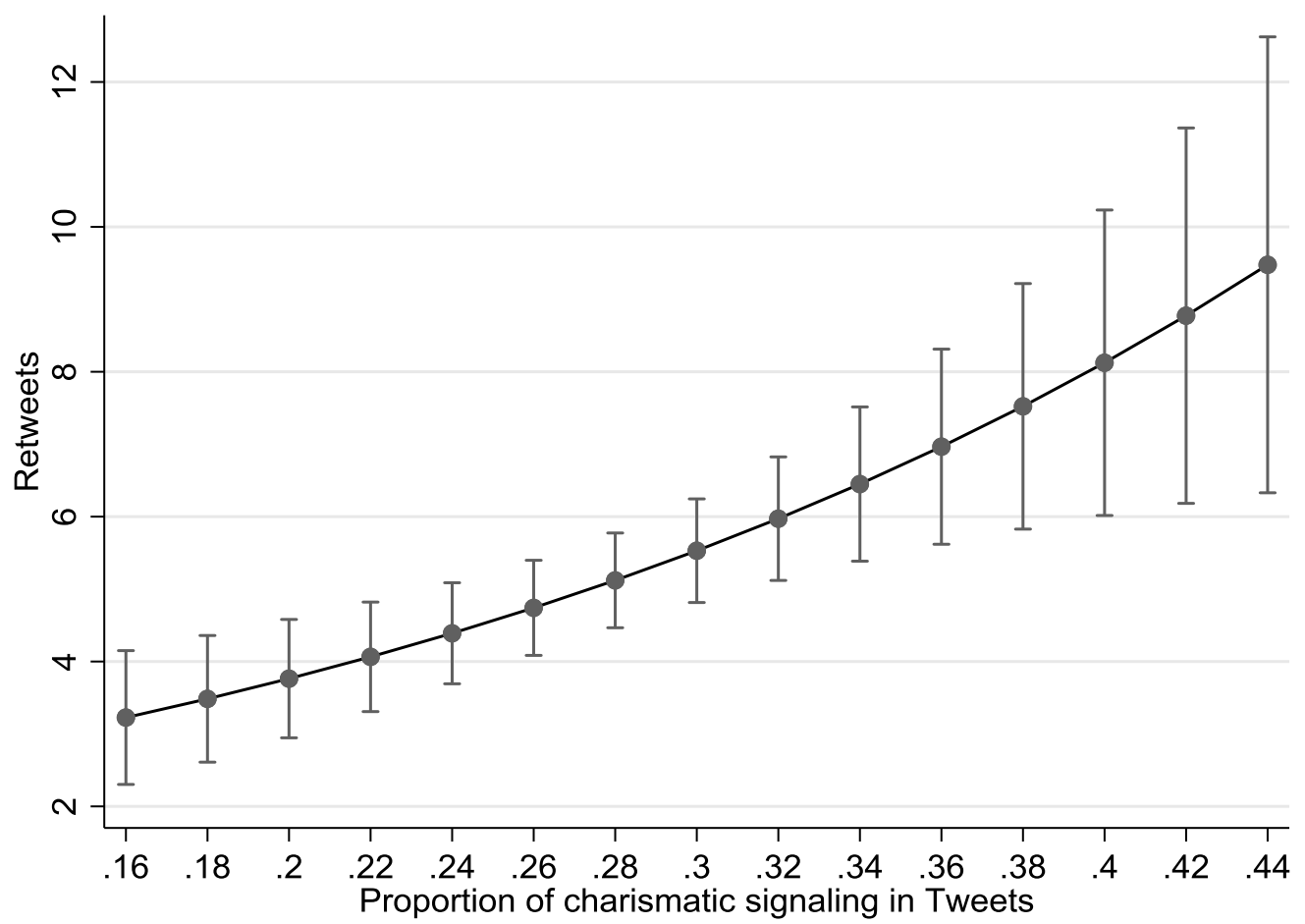


Appendix I: Reanalysis Antonakis et al. (2011) data by splitting verbal and nonverbal charismatic signaling

\begin{tabular}{|c|c|c|c|c|c|c|}
\hline & $\begin{array}{c}(1) \\
\text { Leader } \\
\text { Prototyp. }\end{array}$ & $\begin{array}{c}(2) \\
\text { Leader } \\
\text { Affect }\end{array}$ & $\begin{array}{c}(3) \\
\text { Leader } \\
\text { Trust }\end{array}$ & $\begin{array}{c}(4) \\
\text { Leader } \\
\text { Competen. }\end{array}$ & $\begin{array}{l}(5) \\
\text { Leader } \\
\text { Influen. }\end{array}$ & $\begin{array}{c}(6) \\
\text { Leader } \\
\text { Rank }\end{array}$ \\
\hline \multicolumn{7}{|c|}{ Original results reported in Antonakis et al. (2011) } \\
\hline Charismatic signaling & $\begin{array}{l}5.78^{* * *} \\
(5.28)\end{array}$ & $\begin{array}{l}3.53^{* *} \\
(3.29)\end{array}$ & $\begin{array}{c}2.80^{*} \\
(2.29)\end{array}$ & $\begin{array}{l}5.31 \text { ** } \\
(4.07)\end{array}$ & $\begin{array}{l}4.56^{* *} \\
(3.56)\end{array}$ & $\begin{array}{c}4.01 * * \\
(5.63)\end{array}$ \\
\hline$R$-square; (Pseudo- $R$ for Model 6 & .30 & .22 & .22 & .25 & .26 & .16 \\
\hline \multicolumn{7}{|l|}{ Reanalyses reported below } \\
\hline Charismatic signaling (verbal) & $\begin{array}{l}6.34 * * \\
(6.50)\end{array}$ & $\begin{array}{l}3.38^{* *} \\
(3.61)\end{array}$ & $\begin{array}{c}2.62 * \\
(2.47)\end{array}$ & $\begin{array}{l}5.82 * * \\
(5.15)\end{array}$ & $\begin{array}{l}4.91 * * \\
(4.43)\end{array}$ & $\begin{array}{c}3.78 * * \\
(6.53)\end{array}$ \\
\hline Charismatic signaling (nonverbal) & $\begin{array}{l}-.01 \\
(.02)\end{array}$ & $\begin{array}{c}.35 \\
(.79)\end{array}$ & $\begin{array}{c}.33 \\
(.63)\end{array}$ & $\begin{array}{l}-.01 \\
(.01)\end{array}$ & $\begin{array}{c}.06 \\
(.12)\end{array}$ & $\begin{array}{c}.46 \\
(1.42)\end{array}$ \\
\hline Communication Skills & $\begin{array}{c}-.61 \\
(1.84)\end{array}$ & $\begin{array}{c}-.31 \\
(1.12)\end{array}$ & $\begin{array}{c}-.37 \\
(1.10)\end{array}$ & $\begin{array}{c}-.46 \\
(1.26)\end{array}$ & $\begin{array}{l}-.26 \\
(.69)\end{array}$ & $\begin{array}{l}-.59^{* *} \\
(3.17)\end{array}$ \\
\hline Time & $\begin{array}{l}-.15 \\
(.77)\end{array}$ & $\begin{array}{l}-.01 \\
(.07)\end{array}$ & $\begin{array}{c}-.31 \\
(1.51)\end{array}$ & $\begin{array}{c}-.39 \\
(1.84)\end{array}$ & $\begin{array}{l}-.00 \\
(.01)\end{array}$ & $\begin{array}{l}-.04 \\
(.34)\end{array}$ \\
\hline Rater male & $\begin{array}{c}-.30 \\
(1.65)\end{array}$ & $\begin{array}{c}-.43^{*} \\
(2.44)\end{array}$ & $\begin{array}{c}-.60^{* *} \\
(2.96)\end{array}$ & $\begin{array}{c}-.49 * \\
(2.43)\end{array}$ & $\begin{array}{c}-.37 \\
(1.84)\end{array}$ & $\begin{array}{c}.07 \\
(1.15)\end{array}$ \\
\hline Rater age & $\begin{array}{c}.03 \\
(1.53)\end{array}$ & $\begin{array}{l}-.01 \\
(.56)\end{array}$ & $\begin{array}{c}.03 \\
(1.39)\end{array}$ & $\begin{array}{c}.03 \\
(1.44)\end{array}$ & $\begin{array}{l}.01 \\
(.48)\end{array}$ & $\begin{array}{l}-.00 \\
(.25)\end{array}$ \\
\hline Leader fixed-effects & Incl. & Incl. & Incl. & Incl. & Incl. & Incl. \\
\hline Constant & $\begin{array}{c}5.23 * \\
(2.39)\end{array}$ & $\begin{array}{c}4.77 * \\
(2.55)\end{array}$ & $\begin{array}{l}6.21 * * \\
(2.97)\end{array}$ & $\begin{array}{c}5.26 * \\
(2.26)\end{array}$ & $\begin{array}{c}3.79 \\
(1.64)\end{array}$ & \\
\hline Cut 1 & & & & & & -3.53 \\
\hline Cut 2 & & & & & & -2.57 \\
\hline Cut 3 & & & & & & 1.57 \\
\hline$F(46,134) ;$ Wald $\chi^{2}(46)$ for Model 6 & $9.37 * *$ & $4.30 * *$ & $4.20 * *$ & $7.20 * *$ & $5.71 * *$ & $369.11 * *$ \\
\hline$R$-square; (Pseudo- $R$ for Model 6 & .32 & .22 & .22 & .27 & .27 & .17 \\
\hline
\end{tabular}

